\title{
1 Organic matter bioavailability in tropical coastal waters: the Great Barrier Reef
}

2

3 Christian Lønborg ${ }^{1 *}$, Xosé Antón Álvarez-Salgado ${ }^{2}$, Samantha Duggan $^{1}$ \& Cátia Carreira ${ }^{3}$

$4{ }^{1}$ Australian Institute of Marine Science, PMB No 3, Townsville, Queensland 4810, Australia

$5 \quad 2$ IIM-CSIC, Instituto de Investigacións Mariñas, Eduardo Cabello 6, 36208 Vigo, Spain

$6{ }^{3}$ Departamento de Biologia and CESAM, Universidade de Aveiro, Campus Universitario de

7 Santiago, Aveiro 3810-193, Portugal

$8 \quad$ * Corresponding author:

9 Australian Institute of Marine Science

10 PMB 3, Townsville MC, QLD 4810

11 Australia

12 Phone: $0061(0) 747534382$

13 Fax: $0061(0) 747725852$

14 Email: c.lonborg@aims.gov.au; clonborg@gmail.com

15

16 Running head: Great Barrier Reef organic matter degradation

20 Keywords: particulate organic matter, dissolved organic matter, stoichiometry,

21 bioavailability, degradation rate constants, Great Barrier Reef 


\section{Abstract}

23 Bioavailability of organic matter in tropical coastal ecosystems, and particularly in coral

24 reefs, is largely unknown. In order to ameliorate this gap, we collected samples at three

25 locations during the dry and wet seasons in the Great Barrier Reef and measured

26 changes in particulate (POM) and dissolved (DOM) organic matter concentrations in dark,

27 temperature controlled $\left(22-24^{\circ} \mathrm{C}\right)$, laboratory incubations over 50 days. This allowed

28 determining the bioavailable fractions, stoichiometry and degradation rate constants for both

29 pools. The sites did not show any difference in salinity and therefore, observed differences

30 could be related to factors such as disparities in the biological activity and/or the impact of

31 sediment resuspension rather than to location. Our results demonstrate that $58 \pm 8 \%$ of

32 particulate (POC) and $16 \pm 5 \%$ of dissolved organic carbon (DOC) is bioavailable. These

33 proportions increase when the $\mathrm{N}$ (particulate: $75 \pm 5 \%$; dissolved: $32 \pm 4 \%$ ) or P

34 (particulate: $90 \pm 3 \%$; dissolved: $68 \pm 8 \%$ ) pools are examined, suggesting that compounds

35 containing $\mathrm{C}, \mathrm{N}$ and $\mathrm{P}$ are more reactive than compounds containing only $\mathrm{C}$ and $\mathrm{N}$, which in

36 turn are more labile than compounds containing just $\mathrm{C}$ for both pools. This trend is also

37 confirmed by the degradation rates. Furthermore, our results demonstrate that $94 \%$ and $75 \%$

38 of the bioavailable $\mathrm{N}$ and $\mathrm{P}$ are contained in the organic fraction and that these are able to

39 deliver enough nutrients to sustain phytoplankton productivity in the Great Barrier Reef. Our

40 results emphasise that organic matter is a key and mostly unaccounted part of the $\mathrm{C}, \mathrm{N}$ and $\mathrm{P}$

41 cycles in tropical coastal waters of the Great Barrier Reef. 
Organic matter (OM) plays a key role in the cycling of carbon, nitrogen and phosphorus in marine systems in general and in the coastal ocean in particular (Hedges 2002). OM is a highly complex mixture (Repeta 2015), typically divided, in aquatic systems, into the material that is retained on a filter with a pore size between 0.2 and $0.7 \mu \mathrm{m}$ (particulate organic matter; POM) or passes the filter (dissolved organic matter; DOM). This division is purely operational (Verdugo 2012), but the distinction has implications from the view point of biogeochemical cycles: POM can sink to the sediments while DOM remains in the water column. The POM pool consists of a minor fraction of living biomass (e.g. bacteria, zooplankton) and a major fraction of detritus (e.g. dead cells, faecal pellets), while the DOM pool is mainly lifeless (Hedges 2002). On average DOM concentrations are 1 to 2 orders of magnitude greater than that of POM in coastal waters (Barrón and Duarte 2015).

Coastal waters are amongst the most productive and biogeochemically active zones of the marine biosphere, responsible for $14-33 \%$ of total oceanic production and approximately $80 \%$ of organic matter burial (Gattuso et al. 1998). In these waters, OM originates from either autochthonous or allochthonous sources. The autochthonous OM sources are: plankton organisms (Møller 2004; Nagata and Kirchman 1992), macroalgae (Wada et al. 2008), macrophytes (Søndergaard 1981), sediments (Burdige et al. 2004) and even fish (Dundas 1985). The main allochthonous sources include: atmospheric dry and wet deposition (Jickells et al. 2013; Kieber et al. 2006), submarine groundwater discharge (Santos et al. 2012), rivers, streams and overland flow (Meybeck 1982). Four processes have been identified to remove OM from the water column in coastal waters: 1) biological utilization (e.g., Lønborg et al. 2009b); 2) photochemical reactions, where OM is either transformed into recalcitrant compounds (e.g., Kieber et al. 1997), degraded directly to carbon monoxide or dioxide, or to

66 simpler compounds more bioavailable for bacterial uptake (e.g., Mayer et al. 2011); 3) loss 
via aggregation and sorption leading to sedimentation (Burd and Jackson 2009; Carlson et al. 1985); and 4) abiotic degradation via free radical reactions of OM with oxygen (Rontani et al. 2014). In general, it is assumed that the POM fraction is less degraded and more bioavailable than the DOM pool, but both contain labile compounds with short turnover times (from hours to days), a semi-labile pool with longer turnover times (from weeks to months) and a recalcitrant background pool (Boudreau and Ruddick 1991; Hansell 2013).

Previous studies have shown that both autochthonous and allochthonous OM can be degraded by marine bacteria, with the bioavailability depending on an array of factors including molecular size and structure, environmental conditions such as inorganic nutrient limitation of bacterial activity, redox state, microbial community composition and mineral associations, or extreme dilution of individual molecules (Amon and Benner 1996; Benner and Opsahl 2001; Dittmar 2015; Keil and Mayer 2014; Moran et al. 1999; Thingstad et al. 1999).

Tropical coastal waters harbour some of the most complex and productive ecosystems on Earth, including coral reefs. They receive approximately one order of magnitude more inputs of continental carbon, nitrogen and phosphorus than temperate and artic regions (Brunskill 2010). Phytoplankton production rates in tropical continental shelves and estuaries have also been shown to match some of the most productive areas of the global ocean (i.e. upwelling areas). These high rates have been supported by elevated temperatures and a steady supply of nutrients and solar radiation (Nittrouer et al. 1995). The fate of the terrestrial material, in situ mineralization versus export to the adjacent ocean, depends on erosional and morphological issues. Mineralization is favoured in low erosional river catchments combined with narrow shelves. The Amazon and the Ganges-Brahmaputra catchment areas are extreme cases of low

90 and highly erosional basins that derive in predominant mineralization (Medeiros et al. 2015)

91 and preservation (Galy et al. 2015) of terrestrial OM, respectively. Furthermore, in tropical 
coastal systems with a narrow shelf, such as the coastal waters of the Bismarck Sea, most of the terrestrial material is, together with the OM produced in situ, exported to the open ocean

94 (Brunskill 2010; Burns et al. 2008). On the contrary, in broad shelves, such as the Great

95 Barrier Reef, almost all OM is degraded within the continental shelf (Brunskill et al. 2010).

96 Despite that these coastal systems are productive and important to both regional and global

97 biogeochemical cycles and food webs, few studies have investigated the microbial

98 bioavailability and degradation of both POM and DOM in the water column of tropical

99 coastal waters (Medeiros et al. 2015; Ward et al. 2013) and there is therefore still a lack of

100 mechanistic understanding of which factors influences the OM degradation.

101 In this work we present results from experiments designed to: 1) quantify the seasonal 102 bioavailability of POM and DOM; 2) estimate the POM and DOM stoichiometry during 103 microbial degradation; and 3) determined the POM and DOM degradation rate constants 104 using laboratory incubations in the Great Barrier Reef, Australia.

106 Methods

\section{Study area}

108 The Great Barrier Reef (GBR) is situated on the continental shelf and slope of Australia's

109 northeast coast. The GBR has a maximum width of $330 \mathrm{~km}$ and extents over an area of

$110344,000 \mathrm{~km}^{2}$ (Fig. 1). Approximately $7 \%$ of this area is covered by corals (total of $\sim 3700$

111 reefs) which are primarily located at distance, ranging from $\sim 15$ to $150 \mathrm{~km}$, from shore; with

112 the open water body separating the reef from the mainland known as the GBR lagoon. This

113 lagoon has a water depth of around 10-20 m close to shore increasing to $40 \mathrm{~m}$ towards the

114 reefs, representing an area of around $238,700 \mathrm{~km}^{2}$. Within the central part of the lagoon,

115 currents are primarily equatorward, driven by the predominant south-easterly trade wind 
116 regime from March through October, and winds are more variable during the austral summer

117 (Wolanski 1994).

118 Over the continental slope, the East Australian Current (EAC) flows poleward and enters

119 onto the shelf and outer lagoon by passages between reefs (Fig. 1). The combined effect of

120 currents, tidal mixing and winds does that surface waters of the GBR lagoon are normally

121 well mixed exhibiting very little stratification. The GBR region has a monsoonal climate,

122 characterized by a wet summer (December-March) season and a dry winter season, with

123 around $60 \%$ of the annual rainfall occurring in the wet season.

124 Plankton communities in the GBR are in nearshore waters frequently dominated by diatoms,

125 while further offshore picoplankton unicellular cyanobacteria (Synechococcus) and

126 prochlorophytes (Prochlorococcus) dominate, together with $\mathrm{N}_{2}$-fixing cyanobacteria

127 (Trichodesmium) and assemblages of open-ocean dinoflagellates (Furnas et al. 2005;

128 Revelante and Gilmartin 1982). The average plankton primary productivity varies between

1290.1 and $1.5 \mathrm{~g} \mathrm{C} \mathrm{m}^{-2} \mathrm{~d}^{-1}$ with highest rates in nearshore waters during the summer wet season,

130 while further offshore no clear seasonal signals are found (Furnas et al. 2005). River inputs

131 together with both surface and upwelled water from the Coral Sea, $\mathrm{N}_{2}$ fixation and rain

132 represent the largest external source of nutrients to the system (Furnas et al. 2011). As the

133 magnitude of different sources, sinks and cycling of nutrients (both inorganic and organic) in

134 the GBR is poorly understood, it is currently not possible to confidently state which of these

135 sources are the most important at any given time and place. Dissolved organic matter (DOM)

136 contains around $80 \%$ of the nitrogen and phosphorus forms; particulate nitrogen and

137 phosphorus represent approximately $19 \%$, while the remaining $1 \%$ are contained in the

138 inorganic nutrient pools (Furnas et al. 2011).

139 In this study we determined the bioavailability, stoichiometry and degradation rates of POM

140 and DOM at three stations in the late dry (September 2014), wet (February 2015) and early 
141 dry seasons (June 2015). Fig. 1 shows the three study sites, which all have been sampled

142 frequently over the past 10 years as part of the GBR Marine Monitoring Program (MMP;

143 (Lønborg et al. 2016). These sites were chosen as they are impacted differently by 1) sporadic

144 continental runoff, 2) sediment resuspension events and turbidity levels due to differences in

145 local wind conditions and water depth and 3) upwelled water from the Coral Sea, with sta. 1

146 and 2 likely being influenced and sta. 3 largely unaffected. The three sites furthermore span

147 across the $20 \mathrm{~m}$ bathymetry depth range (sta. $1-16 \mathrm{~m}$; sta. $2-40 \mathrm{~m}$ and sta. $3-23 \mathrm{~m}$ ), with

148 terrigenous materials dominating sediments and suspended matter below this depth and

149 biogenic carbonates at deeper stations (Belperio and Searle 1988).

150

151 Sample collection

152 Meteorological data reported in this study (wind speed and direction) were measured by

153 automatic sensors installed on board the R/V Cape Ferguson. Full-depth continuous

154 conductivity-temperature-depth (CTD) profiles were recorded prior to water collection with a

155 Seabird SBE 37 plus at each sampling site. The CTD salinity was calibrated with water

156 samples collected with the Niskin bottles and analysed in the base laboratory with a Portasal

157 Model 8410A. The observed Secchi-disk depth (in m) was measured as the depth at which a

158 lowered white disk (18 cm diameter) just disappears from the observer's sight. The disk was

159 lowered on the lee side of the vessel in order to minimize wind driven surface ripples and

160 where possible on the sunny side of the vessel. Although the disk does not provide an actual

161 quantitative measure of light penetration, it does provide a method to determine limits of

162 visibility for comparative purposes. Water for the laboratory incubation experiments was

163 collected with a $25 \mathrm{~L}$ Niskin bottle at $5 \mathrm{~m}$ depth, and combined into two $50 \mathrm{~L}$ acid washed

164 containers. 
165 Sample water (1 L) for total suspended solids (TSS) analysis was collected on pre-weighed

$1660.4 \mu \mathrm{m}$ polycarbonate filters (47 mm diameter). After filtration, filters were rinsed with 50

$167 \mathrm{~mL}$ of deionized water to remove salt. TSS concentrations were determined gravimetrically

168 from the mass difference between loaded and unloaded filters after drying overnight at $60^{\circ} \mathrm{C}$.

169 Water for chlorophyll $a(\mathrm{Chl} a)$ determination was filtered (between 100 and $200 \mathrm{~mL}$ )

170 through $\mathrm{GF} / \mathrm{F}$ filters (nominal pore size of about $0.7 \mu \mathrm{m})$, which were frozen $\left(-20^{\circ} \mathrm{C}\right)$ until

171 analysis. Chl $a$ was measured with a Turner Designs 10000R fluorometer after 90\% acetone

172 extraction (Yentsch and Menzel 1963). Field samples were also collected for the analysis of

173 particulate organic carbon (POC), nitrogen (PN) and phosphorus (PP) and dissolved

174 inorganic nutrients $\left(\mathrm{NH}_{4}{ }^{+}, \mathrm{NO}_{3}{ }^{-} / \mathrm{NO}_{2}{ }^{-}\right.$and $\left.\mathrm{HPO}_{4}{ }^{2-}\right)$. It should be noted that as we do not

175 distinguish between the inorganic and organic part of the particulate nitrogen and phosphorus

176 fractions, we therefore refer in this article to particulate nitrogen (PN) and phosphorus

177 fractions (PP). A volume of $250 \mathrm{~mL}$ of sample water was collected under low-vacuum on

178 precombusted GF/F filters for particulate matter and filters were kept frozen $\left(-20^{\circ} \mathrm{C}\right)$ until

179 analysis. Dissolved nutrients were immediately filtered through a $0.45 \mu \mathrm{m}$ filter cartridge

180 (Sartorius MiniSart) into acid-washed $50 \mathrm{~mL}$ HDPE plastic containers and kept frozen ($\left.18120^{\circ} \mathrm{C}\right)$ until analysis.

182

183 Experimental design

184 Filtration of the water for the incubation experiments started within 10 min of collection; one 185 part (45 L of natural seawater) was filtered through a dual-stage $(0.8 \mu \mathrm{m}$ and $0.2 \mu \mathrm{m})$ filter 186 cartridge (Pall-Acropak supor Membrane) which had been pre-washed with $10 \mathrm{~L}$ of Milli-Q

187 water to isolate the dissolved fraction; a second part (50 L of natural seawater) was used to 188 harvest the suspended particles under low vacuum pressure on $142 \mathrm{~mm} 0.2 \mu \mathrm{m}$ filters (Pall, 189 Supor membrane Disc Filter), these were dried and stored at $-20{ }^{\circ} \mathrm{C}$ after collection until 
used within 2 hours; and a third part of the sample water $(5 \mathrm{~L})$ was filtered through precombusted $\left(450^{\circ} \mathrm{C}\right.$ for $\left.4 \mathrm{~h}\right) \mathrm{GF} / \mathrm{C}$ filters (nominal pore size of about $1.2 \mu \mathrm{m}$ ), to establish a microbial culture. After filtration, the $0.2 \mu \mathrm{m}$ filtered seawater was immediately transferred into two 20 L carboy's corresponding to the POM and DOM degradation experiments. For the POM experiment the collected suspended particles from $50 \mathrm{~L}$ of seawater were resuspended in the $0.2 \mu \mathrm{m}$ filtered seawater and the particles were kept homogeneous in suspension during distribution into the incubation containers with a gentle stirring provided by a magnetic stirrer. This was followed by the addition of the microbial inoculum to both experiments, which was added corresponding to $10 \%$ of the total volume. The water for each experiment was thereafter distributed into glass bottles $(500 \mathrm{~mL})$ and incubated in the dark at a constant temperature of $22-24^{\circ} \mathrm{C}$ with four replicate bottles being analysed for each subsampling at day $0,2,4,12$ and 50. Additional bottles for subsampling at day 1 in the POM experiments were collected to follow the soluble part of the DOM and inorganic nutrient pools, which was assumed to be the material released within the first day. During the 50 days incubation period no stirring was applied. All glassware used in the experiments was acid washed $(10 \% \mathrm{HCl}$ for $24 \mathrm{~h})$ and rinsed with Milli-Q water prior to use. Unfiltered water from the POM experiments were used to follow changes in total organic carbon (TOC), total nitrogen (TN) and phosphorus (TP). Samples for the analysis of the dissolved phase were collected from both experiments by filtration through prewashed (250 mL Milli-Q water) 0.2 $\mu \mathrm{m}$ filters (Pall, Supor membrane Disc Filter) to follow dissolved inorganic nitrogen (DIN:

$210 \mathrm{NH}_{4}, \mathrm{NO}_{2}{ }^{-}$and $\mathrm{NO}_{3}{ }^{-}$) and phosphorus (DIP: $\mathrm{HPO}_{4}{ }^{-2}$ ), dissolved organic carbon (DOC), total 211 dissolved nitrogen (TDN) and phosphorus (TDP). Water samples for DIN, DIP, TP and TDP

212 were collected in $20 \mathrm{~mL}$ acid washed polyethylene bottles and kept frozen $\left(-20^{\circ} \mathrm{C}\right)$ until

213 analysis. Sub-samples $(10 \mathrm{~mL})$ for TOC, DOC, TN and TDN analysis were collected in pre214 combusted $\left(450^{\circ} \mathrm{C}, 12\right.$ hours) glass ampoules and preserved by adding $50 \mu \mathrm{L} 25 \% \mathrm{H}_{2} \mathrm{PO}_{4}$. 


\section{Sample measurements}

217 Inorganic nutrients $\left(\mathrm{NH}_{4}{ }^{+}, \mathrm{NO}_{3}{ }^{-} / \mathrm{NO}_{2}{ }^{-}\right.$and $\left.\mathrm{HPO}_{4}{ }^{2-}\right)$ were determined by standard segmented 218 flow analysis (Hansen and Koroleff 1999). The precisions were $\pm 0.01 \mu \mathrm{mol} \mathrm{L}{ }^{-1}$ for $\mathrm{NH}_{4}{ }^{+}, \pm$

$2190.1 \mu \mathrm{mol} \mathrm{L}{ }^{-1}$ for $\mathrm{NO}_{3}{ }^{-} / \mathrm{NO}_{2}{ }^{-}$and $\pm 0.02 \mu \mathrm{mol} \mathrm{L}{ }^{-1}$ for $\mathrm{HPO}_{4}{ }^{2-}$. Field samples for the 220 determination of POC and PN were measured by high temperature combustion $\left(950^{\circ} \mathrm{C}\right)$ using 221 a Shimadzu TOC-V carbon analyser fitted with a SSM-5000A solid sample module, after the 222 inorganic carbon on the filters (e.g. $\mathrm{CaCO}_{3}$ ) had been removed by acidification of the sample 223 with $2 \mathrm{M} \mathrm{HCl}$ (Nieuwenhuize et al. 1994). The analyser was calibrated using AR Grade

224 EDTA for the 5 point standard curve. Field concentrations of PP were determined spectrophotometrically as inorganic $\mathrm{P}$ after digesting the particulate matter in 5\% potassium persulphate. The method was standardised using orthophosphoric acid as the standard for the 4 point calibration curve. We compared peak areas of the filter blanks and standard solutions to ensure consistency between runs with no major deviations found. The TOC, DOC, TN and TDN concentrations were measured by high temperature combustion $\left(720^{\circ} \mathrm{C}\right)$ using a

230 Shimadzu TOC-L carbon analyser coupled in series with a nitric oxide chemiluminescence 231 detector. Prior to analysis, $\mathrm{CO}_{2}$ remaining in the acidified sample water was removed by sparging with $\mathrm{O}_{2}$ carrier gas. Three to five replicate injections of $150 \mu \mathrm{L}$ were performed per sample. Concentrations were determined by subtracting a Milli-Q blank and dividing by the

234 slope of a daily 4 points standard curve made from potassium hydrogen phthalate and 235 glycine. To avoid the small error associated with day-to-day instrument variability, all samples from a given experiment were analysed on a single day. Using the deep ocean

237 reference samples we obtained an average concentration of $42.1 \pm 0.6 \mu \mathrm{mol} \mathrm{L}^{-1}$ for DOC and $23831.3 \pm 0.4 \mu \mathrm{mol} \mathrm{L}-1$ for TDN $(n=40)$. The nominal values provided by the reference 239 laboratory (Prof. Hansell Lab) are $41-44$ and $32.25-33.75 \mu \mathrm{mol} \mathrm{L}^{-1}$ respectively. DON 
concentrations were obtained by subtracting DIN from TDN (DON $=$ TDN - DIN $)$, with the

241 standard error calculated as $\mathrm{SE}_{\mathrm{DON}}^{2}=\mathrm{SE}^{2} \mathrm{TDN}^{2}+\mathrm{SE}^{2}$ DIN. TDP and $\mathrm{TP}$ were measured in

242 triplicate by oxidation to soluble reactive phosphorous with the addition of sulphuric acid and 243 persulfate (Koroleff 1983), following autoclaving at $100^{\circ} \mathrm{C}$ for $90 \mathrm{~min}$. DOP was calculated 244 as the difference between TDP and DIP (DOP = TDP - DIP) with the SE for DOP calculated as: $\mathrm{SE}_{\mathrm{DOP}}^{2}=\mathrm{SE}_{\mathrm{TDP}}^{2}+\mathrm{SE}_{\mathrm{DIP}}^{2}$. The time course changes in particulate concentrations in the POM degradation experiments were calculated as the difference between TOC and DOC for

POC, TN and TDN for PN, and TP and TDP for PP. The corresponding standard errors were calculated as $\mathrm{SE}_{\mathrm{POC}}^{2}=\mathrm{SE}_{\mathrm{TOC}}^{2}+\mathrm{SE}_{\mathrm{DOC}}^{2}, \mathrm{SE}_{\mathrm{PN}}^{2}=\mathrm{SE}_{\mathrm{TN}}^{2}+\mathrm{SE}_{\mathrm{TDN}}^{2}$, and $\mathrm{SE}_{\mathrm{PP}}^{2}=\mathrm{SE}_{\mathrm{TP}}^{2}+$ $\mathrm{SE}^{2}$ TDP, respectively.

The decay of the bioavailable fraction of POM and DOM during the course of the incubations was modelled by a first-order exponential decay function. The unchanging recalcitrant pool was also included in the model. For the POM this was expressed as:

$$
\operatorname{POM}(\mathrm{t})=\mathrm{BPOM} \cdot \exp \left(\mathrm{k}_{\mathrm{POM}} \cdot \mathrm{t}\right)+\mathrm{RPOM}
$$

and for DOM as:

$$
\operatorname{DOM}(\mathrm{t})=\mathrm{BDOM} \cdot \exp \left(\mathrm{k}_{\mathrm{DOM}} \cdot \mathrm{t}\right)+\mathrm{RDOM}
$$

256 Where BPOM and BDOM are the bioavailable pools (in $\mu \mathrm{mol} \mathrm{L}^{-1}$ ), $\mathrm{k}_{\mathrm{POM}}$ and $\mathrm{k}_{\mathrm{DOM}}$ the firstorder degradation rate constants (in $\mathrm{d}^{-1}$ ), $\mathrm{t}$ the time (in days) and RPOM and RDOM the remaining pool after 50 days of incubation (in $\mu \mathrm{mol} \mathrm{L}^{-1}$ ). In this study, the bioavailable pool was defined as the difference between the initial and final concentration. Since the

260 bioavailable and recalcitrant pools are calculated prior to fitting the time evolution of POM

261 and DOM, the only parameter that is adjusted is the degradation rate constant. Note that despite the initial conditions for each degradation experiment were different with respect to abundance of bacteria (varied up to 5 times; data not shown) we did not find any relationship 
between degradation rate constants and abundance. Therefore, we assume that the differences were evened out within days.

266

\section{Statistical analysis}

268 Regression analyses were performed using the best-fit between the two variables $\mathrm{X}$ and $\mathrm{Y}$ obtained by regression model II (Sokal and Rohlf 1995). In the cases where the intercept was not significantly different from zero, it was set to zero and a new slope was calculated. Prior to regressions, normality was checked and the confidence level was set at $95 \%$, with all statistical analyses conducted in Statistica 6.0. Furthermore, T-Student tests were performed to test the significance of differences in environmental conditions between seasons and stations ((Sokal and Rohlf 1995)). Degradation rate constants for the DOM pool, obtained at $22-24^{\circ} \mathrm{C}$, were normalized to $15^{\circ} \mathrm{C}$ to allow comparison with other values reported in the literature. Following Lønborg and Álvarez-Salgado $2012, \mathrm{k}\left(15^{\circ} \mathrm{C}\right)=\mathrm{k}(\mathrm{T})^{*} \mathrm{Q}_{10}{ }^{10 /(15-\mathrm{T})}$ where $\mathrm{k}\left(15^{\circ} \mathrm{C}\right)$ and $\mathrm{k}(\mathrm{T})$ are the decay constants at $15^{\circ} \mathrm{C}$ and $\mathrm{T}^{\circ} \mathrm{C}$ and $\mathrm{Q}_{10}$ is the Arrhenius temperature coefficient, set to 2.2 for $\mathrm{C}, 2.0$ for $\mathrm{N}$ and 1.5 for $\mathrm{P}$.

\section{Results}

\section{Environmental conditions}

282 During the sampling period wind direction was predominantly equatorward with intensities

283 of 6 to $13 \mathrm{~m} \mathrm{~s}^{-1}$, which is characteristic of the trade wind regime normally found in the study 284 area (Table 1). Poleward winds were only found at sta. 3 during the early dry season (Table 285 1). Sta. 1 and 2 could potentially have been impacted by upwelling events that occur mostly

286 from October to March (summer), when the south-easterly trade winds relax and monsoon 287 winds are active. However, a recent study (Benthuysen et al. 2016), which characterized 
upwelling events in the GBR over the period 2010 to 2015 , did not detect any events within the weeks of our sampling times and impact on our results therefore seems unlikely.

290 The observed Secchi-disk depth varied between 1 and $20 \mathrm{~m}$, with highest levels at the most 291 offshore station (sta. 2). TSS concentrations were highest (up to $5.86 \pm 0.74 \mathrm{mg} \mathrm{L}^{-1}$ ) at the 292 nearshore station (sta. 3) and lowest at the offshore station (sta. 2) (Table 1). Suspended 293 matter concentrations increased at all stations with wind speed and the levels were inversely 294 related to Secchi-disk depth $\left(\mathrm{R}^{2}=0.49, \mathrm{p}<0.01\right)$.

295 During the late dry season, surface salinities and temperatures were equal (T-Student, $p>$ 296 0.05) at the three locations with levels of around 35.5 and $25^{\circ} \mathrm{C}$, respectively. Alongside, Chl $297 a$, DIN and DIP showed fairly similar levels at the three sites (T-Student, $p>0.05$ ). (Table

298 1). In the wet season surface salinities were also around 35.5, but temperatures and Chl $a$ 299 values were at the highest, around $28^{\circ} \mathrm{C}$ and up to $0.84 \pm 0.04 \mu \mathrm{g} \mathrm{L}{ }^{-1}$, respectively. Lowest

300 DIN concentrations were measured during this period, while DIP was maintained at a similar 301 level to those found during the other seasons (Table 1). Finally, during the early dry season 302 salinity levels were again around 35.5 , temperatures had decreased to $23-24^{\circ} \mathrm{C}$, comparable to 303 the late dry season, and $\mathrm{Chl} a$ concentrations ranged from $0.29 \pm 0.05$ to $0.54 \pm 0.03 \mu \mathrm{g} \mathrm{L}^{-1}$.

304 The DIN concentrations were at levels comparable to the late dry season, while DIP showed

305 similar concentrations to those measured during the two other seasons (Table 1). Field 306 concentrations of POC varied between $6.5 \pm 0.2$ and $16.2 \pm 0.9 \mu \mathrm{mol} \mathrm{L}^{-1}$, while PN and PP 307 ranged from $0.84 \pm 0.22$ to $2.43 \pm 0.25 \mu \mathrm{mol} \mathrm{L}^{-1}$ and from $0.06 \pm 0.01$ to $0.19 \pm 0.03 \mu \mathrm{mol}$

$308 \mathrm{~L}^{-1}$, respectively (Table 1). The field POC, $\mathrm{PN}$ and PP concentrations were all related $\left(\mathrm{R}^{2}\right.$ 309 varying between 0.61 and $0.91, \mathrm{p}<0.01$ ) with the TSS levels. Since TSS concentrations in 310 the inshore GBR lagoon is dominated by resuspended sediment, it suggests that the changes 311 we measure in field POM concentrations were related to resuspension events (Lambrechts et 312 al. 2010). 
314 Particulate and dissolved organic matter concentrations and bioavailability

315 Initial POC concentrations in the degradation experiments varied between $15 \pm 3$ and $39 \pm 3$

$316 \mu \mathrm{mol} \mathrm{L} \mathrm{L}^{-1}$, while PN and PP ranged from $2.6 \pm 1.4$ to $5.6 \pm 0.3 \mu \mathrm{mol} \mathrm{L}{ }^{-1}$ and from $0.13 \pm 0.04$

317 to $0.38 \pm 0.06 \mu \mathrm{mol} \mathrm{L}^{-1}$, respectively (Table 2 ). The initial DOC concentrations in the DOM

318 degradation experiments varied from $57 \pm 1$ to $84 \pm 2 \mu \mathrm{mol} \mathrm{L}^{-1}$, DON from $4.7 \pm 0.3$ to $6.2 \pm$

$3191.0 \mu \mathrm{mol} \mathrm{L}{ }^{-1}$, and DOP from $0.16 \pm 0.05$ to $0.28 \pm 0.04 \mu \mathrm{mol} \mathrm{L}^{-1}$ (Table 2). These DOM

320 levels were comparable to concentrations normally found in the GBR lagoon (Furnas et al.

321 2011). There was no significant difference in the initial inorganic nutrient and DOM

322 concentrations between the DOM and POM experiments (data not shown), suggesting that

323 our pre-concentration of the suspended solids did not cause any major lysis of plankton cells.

324 Organic matter bioavailability and degradation rates are difficult to measure directly in the

325 field. In our incubations we are unable to account for all processes involved in in-situ OM

326 degradation and the approach is therefore simplistic. The experiments are closed to new

327 production and therefore force the microbial community to use the OM produced in-situ prior

328 to the experiments. In this study we defined the recalcitrant pool as the concentration in the 329 samples taken after 50 days of incubation, but we acknowledge that a true estimate of the 330 recalcitrant pool will probably never be obtained in these type of experiments.

331 After 50 days of incubation bioavailable POM ranged between $7 \pm 5$ and $29 \pm 6 \mu \mathrm{mol} \mathrm{L}^{-1}$

332 for $\mathrm{C}, 2.0 \pm 0.5$ and $4.9 \pm 1.2 \mu \mathrm{mol} \mathrm{L}^{-1}$ for $\mathrm{N}$, and $0.12 \pm 0.05$ and $0.35 \pm 0.16 \mu \mathrm{mol} \mathrm{L}^{-1}$ for $\mathrm{P}$

333 (Table 2; Figure 2). This corresponded to average bioavailable fractions of $58 \pm 8 \%$ (average $334 \pm$ SE) for POC, $75 \pm 6 \%$ for PN, and $90 \pm 3 \%$ for PP (Table 2; Figure 2). Within the initial 4 335 days, a conversion of the particulate pool into new DOM was measured, resulting in a peak 336 DOM concentration at day 4 (Figure 4). After that, decreasing concentrations were found 
until day 50, reaching similar endpoint DOM values as those found in the DOM experiment 338 (Figure 4).

339 In the DOM degradation experiments the bioavailable DOC (BDOC) varied between $6 \pm 5$ 340 and $21 \pm 4 \mu \mathrm{mol} \mathrm{L}{ }^{-1}$ corresponding to $16 \pm 5 \%$ of DOC (average \pm SE), bioavailable DON

341 (BDON) ranged between $1.5 \pm 0.5$ and $2.5 \pm 1.3 \mu \mathrm{mol} \mathrm{L}^{-1}$ representing $32 \pm 4 \%$ of the DON 342 and bioavailable DOP (BDOP) reached values between $0.09 \pm 0.08$ and $0.21 \pm 0.07 \mu \mathrm{mol} \mathrm{L}^{-1}$ 343 corresponding to $68 \pm 8 \%$ of DOP (Table 2; Figure 3 ). BDOM significantly correlated with 344 inorganic nutrients and $\mathrm{Chl} a$ (Table 3), indicating that the differences in DOM 345 bioavailability were related to the variations in plankton biomass and activity. The 346 recalcitrant DOM concentrations were not significantly different in the three experiments, 347 except at sta. 2 during the late dry season that showed very low values (RDOC: $51 \pm 1 \mu \mathrm{mol}$ $\mathrm{L}^{-1}$; RDON: $3.2 \pm 0.3 \mu \mathrm{mol} \mathrm{L}{ }^{-1}$; RDOP: $\left.0.08 \pm 0.04 \mu \mathrm{mol} \mathrm{L}{ }^{-1}\right)$.

\section{Contribution of organic matter to the bioavailable nutrient pools}

351 The contribution of DON and DOP to the regeneration of inorganic nutrients was calculated 352 as the slope of the BDON vs. DIN and BDOP vs. DIP linear regressions showing that $19 \pm$ $5 \%$ of the DIN and $54 \pm 12 \%$ of the DIP originated from the degradation of the bioavailable fractions of DON and DOP, respectively (Eq. 1 and 2; Table 4). Our work also showed that on average POM contained $35 \pm 10 \%$ and $25 \pm 8 \%$, and the DOM fraction contained $60 \pm 10$ $\%$ and $50 \pm 10 \%$ of the total bioavailable $\mathrm{N}$ and $\mathrm{P}$ in this system (Figure 5).

357 Positive linear relationships were found between the bioavailable and total pools for both 358 POM and DOM (Eq. 3 to 8; Table 4), with regression slopes not significantly different from 1. This suggests that when bioavailable concentrations increased by $1 \mu \mathrm{mol} \mathrm{L}{ }^{-1}$, the total pool

360 increased by $1 \mu \mathrm{mol} \mathrm{L}^{-1}$, demonstrating that the variations in concentrations were due to

361 bioavailable components. The origin intercepts of these regressions indicate the average 
recalcitrant POM and DOM levels (Eq. 3 to 8; Table 4). The recalcitrant POM concentrations cannot directly be compared with in-situ levels as we applied a pre-concentration step. For

364 the DOM pool average recalcitrant concentrations were $55 \pm 5 \mu \mathrm{mol} \mathrm{L}^{-1}$ for DOC, $3.4 \pm 0.8$

$365 \mu \mathrm{mol} \mathrm{L}{ }^{-1}$ for DON, and $0.07 \pm 0.03 \mu \mathrm{mol} \mathrm{L}^{-1}$ for DOP (Table 4).

366

367

\section{Organic matter stoichiometry}

368 The average C: N: P stoichiometry for the POM pool was $115( \pm 9): 20( \pm 4): 1$, while the 369 bioavailable POM pool had a lower ratio of $75( \pm 8): 17( \pm 1): 1$ (Figure 6$)$. The average 370 C:N:P stoichiometry of the DOM pool was $332( \pm 27): 25( \pm 2): 1$ and BDOM was $83( \pm$ $37137): 12( \pm 2): 1$ (Figure 6). The C:N:P stoichiometry of the recalcitrant POM $(552( \pm 133): 56$

$372( \pm 22): 1)$ and DOM (936 ( \pm 310$): 58( \pm 21): 1)$ were not different among them and showed that they were particularly N- and P- depleted compared with the total and bioavailable

374 fractions.

\section{Organic matter degradation rates}

377 In order to model the time course of POM and DOM degradation during the incubation experiments we used an exponential model that considers only two pools (Eq. 1 and 2): bioavailable and recalcitrant. Average POM degradation rates were $0.25 \pm 0.05 \mathrm{~d}^{-1}$ (average \pm $\mathrm{SE})$ for POC $\left(k_{\mathrm{POC}}\right), 0.29 \pm 0.04 \mathrm{~d}^{-1}$ for PN $\left(k_{\mathrm{PN}}\right)$ and $0.34 \pm 0.05 \mathrm{~d}^{-1}$ for PP $\left(k_{\mathrm{PP}}\right)$ (Table 5). The degradation rates for the bioavailable DOM pool were lower than for the bioavailable

382 POM pool with average first-order rate constants of $0.13 \pm 0.05 \mathrm{~d}^{-1}$ for DOC $\left(k_{\mathrm{DOC}}\right), 0.16 \pm$ $0.07 \mathrm{~d}^{-1}$ for DON $\left(k_{\mathrm{DON}}\right)$ and $0.24 \pm 0.08 \mathrm{~d}^{-1}$ for DOP $\left(k_{\mathrm{DOP}}\right)$ (Table 5). Positive correlations were also observed between $\mathrm{C}, \mathrm{N}$ and $\mathrm{P}$ degradation rates either for POM (Eq. 9 to 11; Table 4) or DOM (Eq. 12 to 14; Table 4), with the regression slopes, indicating that $\mathrm{N}$ and $\mathrm{P}$ containing compounds (e.g. amino acids) are degraded faster than $\mathrm{N}$ and $\mathrm{P}$ poor compounds 

above. Both the POM and DOM degradation rates were positively correlated with the size of the bioavailable pools (Eq. 15 to 17 and 18 to 20 of Table 4), demonstrating that higher

390 bioavailable concentrations would lead to faster degradation rates. As our POM degradation

391 rates were calculated on concentrated samples they are not directly comparable with in-situ

392 rates. We therefore only calculated half-life time $\left(\ln 2 / \mathrm{k}_{\mathrm{M}}\right)$ for the BDOM pool that were $4.8 \pm$ $1.6 \mathrm{~d}$ for DOC, $3.7 \pm 1.3 \mathrm{~d}$ for DON and $2.7 \pm 0.7 \mathrm{~d}$ for DOP. To compare our DOM degradation rates with other values in the literature, we estimated the first order degradation rate constants at a standard temperature of $15^{\circ} \mathrm{C}$, resulting in average $k_{\mathrm{DOC}}$ of $0.05 \pm 0.02 \mathrm{~d}^{-1}$, $k_{\text {DON }}$ of $0.07 \pm 0.02 \mathrm{~d}^{-1}$ and $k_{\text {DOP }}$ of $0.15 \pm 0.04 \mathrm{~d}^{-1}$, which translate into half-life times of 14.7 $\pm 4.9 \mathrm{~d}$ for DOC, $10.1 \pm 3.4 \mathrm{~d}$ for DON and $4.7 \pm 1.3 \mathrm{~d}$ for DOP.

\section{Discussion}

400 Organic matter (OM) degradation has a major impact on the distribution of carbon, 401 nitrogen and phosphorus in the oceans (Hansell et al. 2009; Hedges 2002; Lønborg and 402 Álvarez-Salgado 2012). At the global coastal ocean scale, about 50\% of the net primary production is supported by pelagic mineralization and an additional $25 \%$ by benthic mineralization of biogenic organic matter (Wollast 1998). Determining the reactivity of OM is therefore critical for our understanding of the ocean carbon, nitrogen and phosphorus cycles. However, few data are available on the amount of labile compounds and the rate of

407 degradation of both POM and DOM in tropical coastal waters.

408

\section{Organic matter bioavailability}

410 The particulate matter collected in our study was a mixture of inorganic particles, living OM

411 and detritus. Because of the shallow nature of the GBR lagoon (especially at sta. 1 and 3) the 
412 water is often turbid (classified as 'case 2' waters) and it has been demonstrated that POM

413 recovered is mainly sediment derived with only a part being produced daily by the plankton

414 community (Furnas et al. 2011; Furnas et al. 2005). At all our stations POM and TSS levels

415 were correlated illustrating the importance of suspended sediment OM in our POM

416 incubation experiments. Sediment OM in the GBR has been shown to be readily degraded

417 with only around $1 \%$ of the combined river and marine OM being preserved in the sediments

418 (Alongi et al. 2007; Brunskill et al. 2002). In accordance with these and studies conducted in

419 other coastal systems we found that a large part of the C, N and P in the POM pool was

420 bioavailable over the 50 days incubation period (Burkhardt et al. 2014; Fujii et al. 2002;

421 Garber 1984; Seiki et al. 1991; Wetz et al. 2008). This high bioavailability fits well with the

422 major contribution of carbohydrates and proteins found in the POM pool of the Great Barrier

423 Reef (Lønborg et al. 2017). But it should also be kept in mind that not all PN and PP in our

424 experiments was organic as parts likely were particle -bound inorganic nitrogen and

425 phosphorus (Eyre 1994; Sanudo-Wilhelmy et al. 2004). Since we did not quantify this

426 contribution, our PN and PP bioavailability are likely overestimated.

427 Particles and aggregates are known to be hot spots of microbial enzymatic activity

428 transforming POM into DOM often at rates faster than can be used, thereby releasing DOM

429 that can be utilized by free-living microbes (Kahler and Koeve 2001; Smith et al. 1992). This

430 enzymatic activity conversion has previously been shown and was also observed in our study

431 (Figure 4). This degradation pattern, as also found in this study, follows three main phases

432 (1) a "leaching phase" resulting in a decrease in particles and increase in DOM and inorganic

433 nutrient concentrations, (2) a "degradation phase" where both POM and DOM are partly

434 converted into microbial biomass and partly respired to $\mathrm{CO}_{2}$ and inorganic nutrients, and

435 finally (3) the "recalcitrant phase" where no further degradation is taking place (e.g. Fukami

436 et al. 1985; Harrison and Mann 1975; Valiela et al. 1984). Previous studies have found that 
around $30 \%$ of phytoplankton-derived OM is bioavailable (Buchan et al. 2014), but in our

438

439

440

441

442

443

444

445

446

447

448

449

450

451

452

454

455

456

457

458

459

460

461

study we found that the recalcitrant DOM concentrations in the POM and DOM were not different, suggesting that the DOM produced during the "leaching" and degradation phases" was bioavailable within the 50 days incubation period.

Our measurements show that DOM had bioavailabilities comparable to the average values reported for coastal waters worldwide (DOC: $22 \pm 12 \%$; DON: $35 \pm 13 \%$; DOP: $70 \pm 18 \%$ ) (Lønborg and Álvarez-Salgado 2012). These were consistently lower than for the POM pool, suggesting a more recalcitrant nature of the DOM pool. This finding is in accordance with the size-reactivity continuum model, which suggests that as OM is degraded it become less bioreactive and smaller in size (Amon and Benner 1996; Benner and Amon 2015). This difference in POM and DOM bioavailability could be linked with the fact that a larger proportion of particulate forms are found in known biochemical classes (e.g. carbohydrates, proteins, lipids, nucleic acids) than in the dissolved fraction, suggesting that in general DOM is more reworked and recalcitrant (Benner 2002; Benner and Kaiser 2003; Hama et al. 2004; Wakeham et al. 1997).

The average recalcitrant DOM concentrations measured in our study (RDOC: $51 \pm 1 \mu \mathrm{mol}$ $\mathrm{L}^{-1}$; RDON: $3.2 \pm 0.3 \mu \mathrm{mol} \mathrm{L}{ }^{-1}$; RDOP: $0.08 \pm 0.04 \mu \mathrm{mol} \mathrm{L}^{-1}$ ), were lower than average values reported for coastal waters worldwide (RDOC: $255 \pm 295 \mu \mathrm{mol} \mathrm{L}{ }^{-1}$; RDON: $10.1 \pm$ $7.3 \mu \mathrm{mol} \mathrm{L}{ }^{-1}$; RDOP: $0.12 \pm 0.07 \mu \mathrm{mol} \mathrm{L}^{-1}$ (Lønborg and Álvarez-Salgado 2012)), but only slightly higher than found in deep ocean water: $35-45 \mu \mathrm{mol} \mathrm{L}{ }^{-1}$ for DOC (Hansell et al. 2009), $3.6 \pm 0.8 \mu \mathrm{mol} \mathrm{L}^{-1}$ for DON (Sipler and Bronk 2015) and $<0.05 \mu \mathrm{mol} \mathrm{L}{ }^{-1}$ for DOP (Karl and Björkman 2015). Recalcitrant DOM in coastal waters have previously been shown to be mainly of terrestrial origin (Lønborg and Álvarez-Salgado 2012), but as our sites had relative high salinities $(>35)$ the ocean influence is predominant and thus, we obtained recalcitrant DOM levels closer to open ocean concentrations. 
The \% POM and DOM bioavailability was variable between experiments, but there was no clear seasonal or location pattern. Organic matter bioavailability has traditionally been

464 linked with its biochemical composition, but more recently it has been shown that molecular 465 structure does not alone control the bioavailability, but depending on environmental factors 466 too (Raymond and Spencer 2015). These factors include changing temperature and nutrient 467 regimes, varying terrestrial inputs, biological production of recalcitrant compounds, sun-light, changing bacterial community and chemical composition, the presence of lithogenic particles and the effect of priming (e.g. Del-Giorgio and Davies 2003; Kawasaki and Benner 2006; Keil and Mayer 2014; Ward et al. 2016). Some studies suggest that the microbial degradation of OM could be limited by inorganic nutrients (Thingstad et al. 1999), which are particularly low in the Great Barrier Reef $\left(<0.25 \mu \mathrm{mol} \mathrm{L}{ }^{-1}\right.$ of DIN, $<0.10 \mu \mathrm{mol} \mathrm{L}^{-1}$ of DIP $)$. We found that the inorganic nutrient concentrations increased over the incubation period, suggesting that over time the microbial degradation was not limited by the nutrient availability. Another factor that also likely influences the bioavailability is the contribution of terrestrial and marine derived matter, with terrestrial material being less bioavailable than marine derived material (Bauer et al. 2013). In our study, as suggested by the salinities ( $>35$ ), the influence of terrestrial derived OM was minor and changes in the bioavailability is therefore more likely related to marine processes. Aquatic microbes have been shown to produce recalcitrant 480 OM when degrading bioavailable compounds (Kawasaki and Benner 2006; Lønborg et al. 481 2009a; Ogawa et al. 2001). These processes did most likely also take place in our experiments but we are unfortunately not able to determine the impact on our results. Sunlight related processes have been shown to both enhance and decrease OM bioavailability, 484 with the impact most likely depending on the microbial community involved and the OM 485 chemical composition (Mayer et al. 2009; Tranvik and Bertilsson 2001). As we conducted 486 our experiments in the dark we cannot assess how sunlight impacts the OM bioavailability. 
487 The microbial community composition varies spatially, seasonally and during incubation experiments (Massana et al. 2001; Teira et al. 2009). Changes in the microbial community most likely occurred during our experiments, but as we did not quantify these changes we are not able to assess how this impacted the bioavailability. There is also growing evidence that some minerals can enhance and others protect OM from microbial degradation (Keil and

492 Mayer 2014). As there were variable levels of inorganic particles present in our field samples

493 (TSS levels reported in Table 1) these were added to our POM experiments. We cannot exclude the possibility that these processes impacted our results, but as we did not find any clear relationship between initial TSS concentrations and particles bioavailability the overall influence is likely minor. The priming effect refers to the observation that addition of labile

497 OM can modify or trigger degradation of previously recalcitrant OM (Blagodatskaya and Kuzyakov 2008). Few studies have investigated these processes in marine waters mostly demonstrating contrasting outcomes, with some suggesting no or negative priming

500 (decreased bioavailability) and others finding positive priming (increased bioavailability)

501 effects (e.g. Carlson et al. 2002; Carlson et al. 2004; Cherrier et al. 1999; Gontikaki et al.

502 2013). Our POM experiments where we added highly labile POM to the DOM pool can be used as an initial test of whether priming is influencing DOM degradation in the GBR. As we did not find any enhanced DOM degradation in those experiments there is no indication of priming. But as our experiments were conducted under lab-based conditions, more complex sets of conditions (e.g. changed microbial community and array of labile substrates) are

507 needed to be tested before it can be concluded if priming is important for the OM cycling in the GBR (Bianchi 2011; Ward et al. 2016).

509 For our bioavailability estimates it should be noted that these are based on laboratory

510 experiments, which ignores that in nature the POM and DOM pools would be mixed with

511 other water masses and OM from different sources. Furthermore, in nature the pools are also 
512 exposed to other water-column processes such as turbulence, photochemical reactions,

513 sedimentation and resuspension that might influence their bioavailability. Despite this

514 limitation our data shows that the POM and DOM pools are partially bioavailable on a time

515 scale of days to weeks.

516 In order to understand the nutrient dynamics in coastal waters it is necessary to account for

517 both inorganic and the bioavailable part of organic nutrients. We show that in oligotrophic

518 tropical coastal waters such as the GBR where the inorganic nutrient concentrations are close

519 to the detection limit levels of the standard methods, on average $95 \pm 2 \%$ of the bioavailable

520 nitrogen and $75 \pm 7 \%$ of the bioavailable phosphorus are contained in the organic fraction.

521 Our study suggests that in the GBR, future work should focus on measuring the total nutrient

522 bioavailability and not only, as previously, focus on inorganic nutrient concentrations.

523

524 Particulate versus dissolved organic matter stoichiometry

525 The stoichiometry of OM is a signature of production and degradation pathways. While the

526 C:N:P ratios of POM and plankton biomass are relatively well constrained at a mean value of

527 106:16:1, i.e. the Redfield ratio (Anderson 1995; Redfield et al. 1963); the elemental ratios of

528 DOM during both production and degradation processes is less well understood (Conan et al.

529 2007; Hopkinson and Vallino 2005).

530 Previous studies in oligotrophic environments have shown that the N:P of particulate

531 matter tended to exceed the Redfield ratio of 16 (e.g. Hebel and Karl 2001). In contrast, in

532 the GBR the $\mathrm{C}: \mathrm{N}: \mathrm{P}$ ratios in suspended particulate matter are very close to Redfield ratio

533 (Average: 115:14:1, $n=838$ ), suggesting a major contribution of plankton sourced material

534 and a minor influence of continental OM (e.g. mangroves, salt marshes, seagrasses) which

535 have higher C:N:P ratios (Vitousek et al. 1988). On the other hand, the DOM pool in the 
536 GBR has average ratios much higher than Redfield $(302: 27: 1, n=1011)$. Both the POM and

537 DOM ratios show only minor temporally or cross-shelf variations (Furnas et al. 2005).

538 The stoichiometry of both the bioavailable POM and DOM pools is compatible with the

539 product of synthesis and early degradation of marine phytoplankton (Anderson 1995; Garber

540 1984; Redfield et al. 1963). Therefore, the DOM is degraded with a C: N : P ratio

541 substantially lower than for the bulk pool. In coastal waters the BDOM stoichiometry has

542 been shown to vary between $483: 38: 1$ and $57: 13: 1$, with an overall average of $197: 25: 1$

543 (Lønborg and Álvarez-Salgado 2012), which is comparable to ratios found in the open ocean

544 (300: 22:1, Benner 2002 ; 199: 20: 1, Hopkinson and Vallino 2005 ; 317:39:1, Letscher and

545 Moore 2015). Our estimate $(83( \pm 37): 12( \pm 2): 1)$ is lower than these average values, which

546 could be linked with difference in the plankton release of C-rich labile compounds (e.g.

547 mono- and polysaccharides) (Fajon et al. 1999), chemical composition, and/or changes in the

548 production and degradation pathways between systems (Torres-Valdes et al. 2009). The

549 stoichiometry of both the bioavailable POM and DOM concurs with both the fractionation

550 during $\mathrm{OM}$ degradation, and our finding of the $\mathrm{C}, \mathrm{N}$ and $\mathrm{P}$ containing compounds being more

551 bioavailable than the $\mathrm{C}$ and $\mathrm{N}$ containing compounds that are in turn more bioavailable than

$552 \mathrm{C}$ containing compounds. This therefore explains the increasing $\mathrm{C}: \mathrm{N}$ and $\mathrm{C}: \mathrm{P}$ ratios found

553 with depth for exported OM in the deep ocean and in microbial degradation experiments

554 (Berggren et al. 2015; Boyd and Trull 2007; Hopkinson and Vallino 2005; Lønborg and

555 Álvarez-Salgado 2012 and references therein).

556 Conversely, the C:N:P stoichiometry of the recalcitrant POM and DOM pools were

557 characterized by being extremely N- and P- depleted compared to the bioavailable fraction.

558 It is remarkable that the $\mathrm{C}: \mathrm{N}: \mathrm{P}$ ratios found for both the recalcitrant POM $(552( \pm 133): 56( \pm$

559 22):1) and DOM pools (936 ( \pm 310$): 58( \pm 21): 1)$ were less $\mathrm{N}$ - and P- depleted than values

560 reported for open (3511:202:1), coastal (2835: 159: 1) and terrestrial recalcitrant OM 
561 (3495: 118: 1) (Hopkinson and Vallino 2005; Lønborg and Álvarez-Salgado 2012; Meybeck

562 1982). This relative $\mathrm{N}$ and $\mathrm{P}$ enrichment could be due to that our incubation period was short

563 (50 days) and therefore not all semi-labile OM was consumed. In any case, recalcitrant DOM

564 can be then considered as the DOM that was not utilized by heterotrophic bacteria during the

565 incubation independently of what was the cause behind: recalcitrant chemical structure,

566 environmental conditions, extreme dilution of individual molecules, etc. (Dittmar 2015; Goto

567 et al. 2017). Although recalcitrant DOM can be produced by abiotic processes, recent

568 incubation experiments have also demonstrated that the molecular and structural properties of

569 microbial derived DOM are consistent with those of the recalcitrant molecules in the ocean

570 (Lechtenfeld et al. 2015; Osterholz et al. 2015). Concerning the molecular composition of

571 recalcitrant DOM, carboxyl-rich aliphatic materials, CRAM (Hertkorn et al. 2006),

572 polyaromatic compounds (Dittmar and Paeng 2009) and, to a minor extend, humic-like

573 materials (Catala et al. 2015; Yamashita and Tanoue 2008) have been already identified. All

574 of them are $\mathrm{N}$ and $\mathrm{P}$ depleted compounds.

575

576

577 Organic matter degradation rates

578 Biologically produced OM has different reactivates, with degradation being a multi-step

579 process, as the pool contains a spectrum of reactive compounds, each with its own rate of

580 degradation (e.g. Vahatalo et al. 2010). However, in most studies degradation has been

581 modelled assuming exponential decay and one bioavailable pool decaying with a first-order

582 rate constant.

583 The rates of OM degradation have previously been shown to vary depending on the

584 microbial community composition, redox state, environmental conditions and

585 sorption/desorption of organic molecules to particles (Keil and Mayer 2014). The rates we 
determined in this study are not directly comparable with in-situ rates as we e.g. diluted the

587 microbial community, applied a pre-concentration step in the POM experiment and ignored the influence of various processes including turbulence and photochemical reactions.

In spite of these limitations, our data demonstrate that natural derived POM and DOM can

590 be degraded on timescales of days (e.g. Bendtsen et al. 2015; Burkhardt et al. 2014; Seiki et al. 1991; Wetz et al. 2008) and that the microbial degradation slowed down over time reaching a stable level at the end of the experiments. Both the POM and DOM degradation rates were positively correlated with the bioavailable pool (Table 2), demonstrating that

594 higher bioavailable concentrations would lead to faster degradation, as also observed previously (e.g. Hopkinson et al. 1997; Lønborg et al. 2009b). Positive correlation was observed between $\mathrm{C}, \mathrm{N}$ and $\mathrm{P}$ degradation rates for the POM and DOM pools. The corresponding linear regression slopes, indicated that the POC and DOC pools were degraded at a rate equivalent to $73 \pm 26$ and $55 \pm 6 \%$ (slope \pm SE) of PP and DOP, respectively (Table 4). While the PN and DON pools were degraded at a rate equivalent to $85 \pm 27 \%$ and $67 \pm$

$60015 \%$ of PP and DOP, respectively (Table 4). This is in agreement with the bioavailability and 601 the $\mathrm{C}: \mathrm{N}: \mathrm{P}$ stoichiometry estimates, demonstrating that $\mathrm{C}, \mathrm{N}$ and $\mathrm{P}$-containing molecules are 602 more reactive than $\mathrm{C}$ and $\mathrm{N}$ - containing molecules, which in turn are more labile than $\mathrm{C}$ containing molecules.

604 The degradation of POM has been studied extensively in open ocean waters with 605 degradation rate constants estimated in laboratory and field settings using both natural and 606 specific OM sources (e.g. phytoplankton cells, faecal pellets) (e.g. Goutx et al. 2007; Harvey 607 and Macko 1997; Harvey et al. 1995; Panagiotopoulos et al. 2002; Sempéré et al. 2000). 608 Previous studies have shown that the POC exponential degradation constants vary widely 609 (approx. range $0.001-0.72 \mathrm{~d}^{-1}$ ) both between studies and with source material, with most 610 rates reported for POC and fewer for PN and PP (Goutx et al. 2007; Harvey et al. 1995; 
611 Panagiotopoulos et al. 2002). Our average POM degradation rate $\left(0.25 \pm 0.05 \mathrm{~d}^{-1}\right.$ for POC;

$6120.29 \pm 0.04 \mathrm{~d}^{-1}$ for PN and $0.34 \pm 0.05 \mathrm{~d}^{-1}$ for PP at $22-24^{\circ} \mathrm{C}$ ) were similar between stations

613 and seasons. The POC rates were $1 / 2$ to $1 / 3$ lower than rates obtained at similar temperatures

614 for freshly produced phytoplankton POC $\left(\sim 19^{\circ} \mathrm{C}\right.$, Harvey et al. $1995 ; 27^{\circ} \mathrm{C}$, Hama et al.

615 2004), but comparable to rates found for the degradation of amino acids $\left(0.13 \pm 0.03 \mathrm{~d}^{-1}\right)$,

616 lipids $\left(0.24 \pm 0.11 \mathrm{~d}^{-1}\right)$ and natural organic material (range from 0.01 to $\left.0.50 \mathrm{~d}^{-1}\right)$ collected in

617 sediment traps (Belcher et al. 2016; Boyd et al. 2015; Goutx et al. 2007; Mcdonnell et al.

618 2015).

619 Degradation rates for the DOM pool obtained from incubation experiments vary widely

620 with DOC rates (normalized to $15^{\circ} \mathrm{C}$ ) ranging between $0.001 \mathrm{~d}^{-1}$ for samples collected in

621 Florida Bay (Boyer et al. 2006) and up to as high as $0.97 \mathrm{~d}^{-1}$ for plankton derived material

622 collected off the coast of Oregon (Wetz et al. 2008). In our experiments the DOM

623 degradation rates $\left(0.13 \pm 0.05 \mathrm{~d}^{-1}\right.$ for DOC, $0.16 \pm 0.07 \mathrm{~d}^{-1}$ for DON and $0.24 \pm 0.08 \mathrm{~d}^{-1}$ for

624 DOP) were similar to average values reported for coastal waters (Lønborg and Álvarez-

625 Salgado 2012) and showed generally similar rates between stations and seasons. As both the

626 POM and DOM rates did not shown any seasonal or spatial difference it points to similarities

627 within each pool in the biochemical composition and the factors controlling the rates. This

628 lack of variability is in line with previous studies in the GBR showing only minor seasonal

629 and spatial differences in plankton productivity and metabolism, and in the contribution of

630 carbohydrates and proteins to the POM and DOM pools (Furnas and Mitchell 1987; Lønborg

631 et al. 2017; Mckinnon et al. 2013).

632 In the warm oligotrophic waters of the GBR the phytoplankton community shows rapid

633 growth and relative high productivity, which is thought to be fuelled by a steady supply of

634 nutrients from OM degradation (Furnas et al. 2005). Despite the importance of these

635 processes in sustaining productivity few studies have investigating the element cycling in the 
636 GBR. One such study investigated the ammonium regeneration rates using a stable isotope 637 approach at Davies Reef, south of our study area, measuring an average production rate of $6380.10 \pm 0.01 \mu \mathrm{mol} \mathrm{N} \mathrm{L} \mathrm{d}^{-1}$ (ranging from undetectable up to $0.27 \mu \mathrm{mol} \mathrm{N} \mathrm{L}^{-1} \mathrm{~d}^{-1}$; (Hopkinson 639 et al. 1987). Another study estimated that on average a daily supply of $0.24 \mu \mathrm{mol} \mathrm{N} \mathrm{L} \mathrm{L}^{-1}$ and $640 \quad 0.015 \mu \mathrm{mol} \mathrm{P} \mathrm{L} \mathrm{L}^{-1}$ was needed to sustain the plankton primary productivity (Furnas et al. 641 2005). If we assume that the bioavailable compounds are replenished on a daily scale and all 642 POM is available for degradation, we can use our degradation rates to calculate a likely upper 643 limit for the nitrogen and phosphorus supplied by POM and DOM degradation. This 644 calculation shows that the POM pool could provide on average $0.35 \pm 0.17 \mu \mathrm{mol} \mathrm{N} \mathrm{L} \mathrm{d}^{-1}$ 645 and $0.03 \pm 0.02 \mu \mathrm{mol} \mathrm{P} \mathrm{L}{ }^{-1} \mathrm{~d}^{-1}$, while the DOM pool could supply $0.33 \pm 0.15 \mu \mathrm{mol} \mathrm{N} \mathrm{L} \mathrm{L}^{-1} \mathrm{~d}^{-1}$ 646 and $0.03 \pm 0.11 \mu \mathrm{mol} \mathrm{P} \mathrm{L}^{-1} \mathrm{~d}^{-1}$. These values are, individually and combined, larger than the 647 daily supply needed, suggesting that the OM pool contains sufficient labile material to fuel 648 the plankton primary productivity in the GBR.

649 From a biogeochemical perspective, it is important to compare our degradation rates with 650 the residence times to determine if the bioavailable $\mathrm{OM}$ is degraded before being transported 651 into the Coral Sea through physical processes (e.g. cross-shelf mixing or advection).

652 Different approaches (e.g. hydrodynamic models and satellite tracked drifters) have been 653 used to calculate the residence time in the GBR providing very diverse estimates (varying 654 between 7 and 430 days; Choukroun et al. 2010; Luick et al. 2007). In this study we 655 therefore chose to use a conservative estimate of the residence time ( 2 weeks; Choukroun et 656 al. 2010) to compare with our degradation rates and half-life times. From these estimates it is 657 clear that most of the bioavailable POM and DOM would be consumed (BPOM $>96 \%$;

658 BDOM $>83 \%$ ) within the system before reaching the outer shelf. The fractionation we 659 measured also suggests that the material that would be exported to the sediment (POM), 660 and/or to the Coral Sea (DOM), will be carbon rich, which might influence the N/P limitation 
of the receiving systems. This finding is in agreement with a previous attempt to balance the

662 GBR carbon budget using a radioisotope approach, which suggested a near balance between

663 production and respiration and following a small export of $\mathrm{C}, \mathrm{N}$ and $\mathrm{P}$ from the GBR lagoon

664 to the Coral Sea (Brunskill et al. 2010).

665

666

\section{Conclusions}

667 In this study, we demonstrate that in the coastal waters of the GBR: 1) the bioavailability

of the POM pool is much larger than for the DOM pool; 2 ) on average $95 \pm 2 \%$ of the

bioavailable nitrogen and $75 \pm 7 \%$ of the bioavailable phosphorus are contained in the

670

organic fraction; 3 ) the bioavailable POM pool has a stoichiometry demonstrating a

671

preferential degradation of $\mathrm{N}$-rich materials, i.e. proteins, compared to the average Redfield

ratio, while the bioavailable DOM is enriched in $\mathrm{N}$ and $\mathrm{P}$ compared with the whole pool; 4)

the degradation rates suggest that the organic fraction contains sufficient labile material to

sustain the GBR plankton primary productivity in the GBR; and 5) most of the bioavailable

POM and DOM is consumed within the GBR lagoon and thus there is only a small export of

$\mathrm{C}, \mathrm{N}$ and $\mathrm{P}$ to the Coral Sea.

\section{References}

678

679

680

681

682

683

684

685

686

687

688

689

690

691

692
Alongi, D. M., and A. D. Mckinnon. 2005. The cycling and fate of terrestrially-derived sediments and nutrients in the coastal zone of the Great Barrier Reef shelf. Mar Pollut Bull 51: 239-252.

Alongi, D. M., L. A. Trott, and J. Pfitzner. 2007. Biogeochemistry of inter-reef sediments on the northern and central Great Barrier Reef. Coral Reefs 27: 407-420.

Amon, R. M. W., and R. Benner. 1996. Bacterial utilization of different size classes of dissolved organic matter. Limnology and Oceanography 41: 41-51.

Anderson, L. A. 1995. On the hydrogen and oxygen content of marine phytoplankton. DeepSea research part I 42: 1675-1680.

Barrón, C., and C. M. Duarte. 2015. Dissolved organic carbon pools and export from the coastal ocean. Global Biogeochemical Cycles 29: 1725-1738.

Bauer, J. E., W. J. Cai, P. A. Raymond, T. S. Bianchi, C. S. Hopkinson, and P. A. Regnier. 2013. The changing carbon cycle of the coastal ocean. Nature 504: 61-70.

Belcher, A., M. Iversen, C. Manno, S. A. Henson, G. A. Tarling, and R. Sanders. 2016. The role of particle associated microbes in remineralization of fecal pellets in the upper 
mesopelagic of the Scotia Sea, Antarctica. Limnology and Oceanography 61: 10491064.

Belperio, A. P., and D. E. Searle. 1988. Terrigenous and Carbonate Sedimentation in the Great Barrier Reef Province, p. 143-174. In L. J. Doyle and H. H. Robert [eds.], Carbonate to Clastic Facies Changes. Developments in Sedimentology. Elsevier Science Publishers.

Bendtsen, J., K. M. Hilligsøe, J. L. S. Hansen, and K. Richardson. 2015. Analysis of remineralisation, lability, temperature sensitivity and structural composition of organic matter from the upper ocean. Progress in Oceanography 130: 125-145.

Benner, R. 2002. Chemical composition and reactivity, p. 59-90. In D. Hansell and C. Carlson [eds.], Biogeochemistry of marine dissolved organic matter. Academic Press.

Benner, R., and R. M. Amon. 2015. The size-reactivity continuum of major bioelements in the ocean. Annual review of marine science 7: 185-205.

Benner, R., and K. Kaiser. 2003. Abundance of amino sugars and peptidoglycan in marine particulate and dissolved organic matter. Limnology and Oceanography 48: 118-128.

Benner, R., and S. Opsahl. 2001. Molecular indicators of the sources and transformations of dissolved organic matter in the Mississippi river plume. Organic Geochemistry 32: 597-611.

Benthuysen, J. A., H. Tonin, B. R., M. Herzfeld, and C. Steinberg. 2016. Intrusive upwelling in the Central Great Barrier Reef. Journal of Geophysical Research: Oceans.

Berggren, M., R. A. Sponseller, A. R. Alves Soares, and A. K. Bergstrom. 2015. Toward an ecologically meaningful view of resource stoichiometry in DOM-dominated aquatic systems. J Plankton Res 37: 489-499.

Bianchi, T. S. 2011. The role of terrestrially derived organic carbon in the coastal ocean: a changing paradigm and the priming effect. Proceedings of the National Academy of Sciences of the United States of America 108: 19473-19481.

Blagodatskaya, E., and Y. Kuzyakov. 2008. Mechanisms of real and apparent priming effects and their dependence on soil microbial biomass and community structure: critical review. Biology and Fertility of Soils 45: 115-131.

Boudreau, B. P., and B. R. Ruddick. 1991. On a reactive continuum representation of organic matter diagenesis. American Journal of Science 291: 507-538.

Bouillon, S., and R. D. Conolly. 2009. Carbon exchange among tropical coastal ecosystems, p. 45-70. In N. I. [ed.], Ecological connectivity among tropical coastal ecosystems. Springer.

Boyd, P. W., A. Mcdonnell, J. Valdez, D. Lefevre, and M. P. Gall. 2015. RESPIRE: An in situ particle interceptor to conduct particle remineralization and microbial dynamics studies in the oceans' Twilight Zone. Limnology and Oceanography: Methods 13: 494-508.

Boyd, P. W., and T. W. Trull. 2007. Understanding the export of biogenic particles in oceanic waters: Is there consensus? Progress in Oceanography 72: 276-312.

Boyer, J. N., S. K. Dailey, P. J. Gibson, M. T. Rogers, and D. Mir-Gonzalez. 2006. The role of dissolved organic matter bioavailability in promoting phytoplankton blooms in Florida Bay. Hydrobiologia 569: 71-85.

Brunskill, G. J. 2010. An overview of tropical margins, p. 423-426. In K.-K. Liu, Atkinson, L., Quinones, R., Talaue-McManus, L. [ed.], Carbon and Nutrient fluxes in Continental Margins: a Global Synthesis. Springer.

Brunskill, G. J., I. Zagorskis, and J. Pfitzner. 2002. Carbon Burial Rates in Sediments and a Carbon Mass Balance for the Herbert River Region of the Great Barrier Reef Continental Shelf, North Queensland, Australia. Estuarine, Coastal and Shelf Science 54: 677-700. 
---. 2010. Tropical coastal seas of australia and Pupua New Guinea, p. 482-493. In K.-K. Liu, L. Atkinson, R. Quinones and L. Talaue-McManus [eds.], Carbon and Nutrient fluxes in Continental Margins: a Global Synthesis. Springer.

Buchan, A., G. R. Lecleir, C. A. Gulvik, and J. M. Gonzalez. 2014. Master recyclers: features and functions of bacteria associated with phytoplankton blooms. Nature reviews. Microbiology 12: 686-698.

Burd, A. B., and G. A. Jackson. 2009. Particle aggregation. Annual review of marine science 1: $65-90$.

Burdige, D. J., S. W. Kline, and W. Chen. 2004. Fluorescent dissolved organic matter in marine sediment pore waters. Marine Chemistry 89: 289-311.

Burkhardt, B. G., K. S. Watkins-Brandt, D. Defforey, A. Paytan, and A. E. White. 2014. Remineralization of phytoplankton-derived organic matter by natural populations of heterotrophic bacteria. Marine Chemistry 163: 1-9.

Burns, K. A., G. Brunskill, D. Brinkman, and I. Zagorskis. 2008. Organic carbon and nutrient fluxes to the coastal zone from the Sepik River outflow. Continental Shelf Research 28: $283-301$.

Carlson, C. A. and others 2002. Effect of nutrient amendments on bacterioplankton production, community structure, and DOC utilization in the northwestern Sargasso Sea. Aquatic Microbial Ecology 30: 19-36.

Carlson, C. A., S. J. Giovannoni, D. A. Hansell, S. J. Goldberg, R. Parsons, and K. Vergin. 2004. Interactions among dissolved organic carbon, microbial processes, and community structure in the mesopelagic zone of the northwestern Sargasso Sea. Limnology and Oceanography 49: 1073-1083.

Carlson, D. J., M. L. Brann, T. H. Mague, and L. M. Mayer. 1985. Molecular weight distribution of dissolved organic materials in seawater determined by ultrafiltration: A re-examination Marine Chemistry 16: 155-171.

Catala, T. S. and others 2015. Turnover time of fluorescent dissolved organic matter in the dark global ocean. Nature communications 6: 5986.

Cherrier, J., J. E. Bauer, E. R. M. Druffel, R. B. Coffin, and J. P. Chanton. 1999. Radiocarbon in marine bacteria: evidence for the ages of assimilated carbon. Limnology and oceanography 44: 730-736.

Choukroun, S., P. V. Ridd, R. Brinkman, and L. I. W. Mckinna. 2010. On the surface circulation in the western Coral Sea and residence times in the Great Barrier Reef. Journal of Geophysical Research 115.

Conan, P. and others 2007. Partitioning of organic production in marine plankton communities:The effects of inorganic nutrient ratios and community composition on new dissolved organic matter. Limnology and Oceanography 52: $753-765$.

Del-Giorgio, P., and J. Davies. 2003. Patterns of dissolved organic matter lability and consumption across aquatic ecosystems, p. 399-424. In S. E. G. Findlay and R. L. Sinsabaugh [eds.], Aquatic ecosystems: Interactivity of dissolved organic matter. Academic Press.

Dittmar, T. 2015. Reasons Behind the Long-Term Stability of Dissolved Organic Matter, p. 369-388. In D. A. Hansell and C. A. Carlson [eds.], Biogeochemistry of Marine Dissolved Organic Matter.

Dittmar, T., and J. Paeng. 2009. A heat-induced molecular signature in marine dissolved organic matter. Nature Geoscience 2: 175-179.

Dundas, I. E. D. 1985. Fate and possible effects of excessive sperm released during spawning. Marine Ecology Progress Series 30: 287-290.

Eyre, B. D. 1994. Nutrient biogeochemistry in the tropical Moresby River estuary system North Queensland, Australia. Estuarine, Coastal and Shelf Science 39: 15-31. 
Fajon, C. and others 1999. The accumulation and release of polysaccharides by planktonic cells and the subsequent bacterial response during a controlled experiment FEMS Microbiology Ecology 29: 351-363.

Fujii, M. and others 2002. Decomposition of phytoplankton in seawater. Part 1. Kinetic analysis of the eff ect of organic matter concentration. Journal of oceanography 58: $433-438$.

Fukami, K., U. Simidu, and N. Taga. 1985. Microbial decomposition of phyto- and zooplankton in seawater. I. Changes in organic matter. Marine ecology progress series 21: $1-5$.

Furnas, M., D. Alongi, D. Mckinnon, L. Trott, and M. Skuza. 2011. Regional-scale nitrogen and phosphorus budgets for the northern $\left(14^{\circ} \mathrm{S}\right)$ and central $\left(17^{\circ} \mathrm{S}\right)$ Great Barrier Reef shelf ecosystem. Continental Shelf Research 31: 1967-1990.

Furnas, M., A. Mitchell, M. Skuza, and J. Brodie. 2005. In the other 90\%: phytoplankton responses to enhanced nutrient availability in the Great Barrier Reef Lagoon. Mar Pollut Bull 51: 253-265.

Furnas, M. J., and A. W. Mitchell. 1987. Phytoplankton dynamics in the central Great Barrier Reef-II. Primary production. Continental Shelf Research 7: 1049-1062.

Galy, V., B. Peucker-Ehrenbrink, and T. Eglinton. 2015. Global carbon export from the terrestrial biosphere controlled by erosion. Nature 521: 204-207.

Gan, S., Y. Wu, and J. Zhang. 2016. Bioavailability of dissolved organic carbon linked with the regional carbon cycle in the East China Sea. Deep Sea Research Part II: Topical Studies in Oceanography 124: 19-28.

Garber, J. H. 1984. Laboratory study of nitrogen and phosphorus remineralization during the decomposition of coastal plankton and seston. Estuarine, Coastal and Shelf science 18: $685-702$.

Gattuso J.-P., M. Frankignoulle, and W. R. 1998. Carbon and carbonate metabolism in coastal aquatic ecosystems. Annual Review of Ecology and Systematics 29: 405-434.

Gontikaki, E., B. Thornton, V. A. Huvenne, and U. Witte. 2013. Negative priming effect on organic matter mineralisation in NE Atlantic slope sediments. PloS one 8: e67722.

Goto, S., Y. Tada, K. Suzuki, and Y. Yamashita. 2017. Production and Reutilization of Fluorescent Dissolved Organic Matter by a Marine Bacterial Strain, Alteromonas macleodii. Frontiers in microbiology 8: 507.

Goutx, M. and others 2007. Composition and degradation of marine particles with different settling velocities in the northwestern Mediterranean Sea. Limnology and oceanography 52: 1645-1664.

Hama, T., K. Yanagi, and J. Hama. 2004. Decrease in molecular weight of photosynthetic products of marine phytoplankton during early diagenesis. Limnology and Oceanography 49: 471-481.

Hansell, D. A. 2013. Recalcitrant dissolved organic carbon fractions. Annual review of marine science 5: 421-445.

Hansell, D. A., C. A. Carlson, D. J. Repeta, and R. Schlitzer. 2009. Dissolved organic matter in the ocean: New insights stimulated by a controversy. Oceanography 22: 202-211.

Hansen, H. P., and F. Koroleff. 1999. Automated chemical analysis, p. 159-226. In K. Grasshoff, K. Kermling and M. Ehrhardt [eds.], Methods of seawater analysis. Wiley$\mathrm{VCH}$.

Harrison, P. G., and K. H. Mann. 1975. Detritus formation from eelgrass (Zostera marina L.): the relative effects of fragmentation, leaching, and decay. Limnology and oceanography 20: 924-934. 
Harvey, H. R., and S. A. Macko. 1997. Kinetics of phytoplankton decay during simulated sedimentation: changes in lipids under oxic and anoxic conditions. Organic Geochemistry 27: 129-140.

Harvey, H. R., J. H. Tuttle, and J. T. Bell. 1995. Kinetics of phytoplankton decay during simulated sedimentation: Changes in biochemical composition and microbial activity under oxic and anoxic conditions. Geochimica et Cosmochimica Acta 59: 3367-3377.

Hebel, D. V., and D. M. Karl. 2001. Seasonal, interannual and decadal variations in particulate matter concentrations and composition in the subtropical North Pacific Ocean. Deep Sea Research Part II: Topical Studies in Oceanography 48: 1669-1695.

Hedges, J. I. 2002. Why dissolved organic matter? , p. 1-33. In D. A. Hansell and C. A. Carlson [eds.], Biogeochemistry of marine dissolved organic matter. Academic Press.

Hertkorn, N. and others 2006. Characterization of a major refractory component of marine dissolved organic matter. Geochimica et Cosmochimica Acta 70: 2990-3010.

Hopkinson, C. S., B. Fry, and A. L. Nolin. 1997. Stoichiometry of dissolved organic matter dynamics on the continental shelf of the northeastern U.S.A. Continental Shelf Research 17: 473-489.

Hopkinson, C. S., B. F. Sherr, and H. Ducklow. 1987. Microbial regeneration of ammonium in the water column of Davies Reef, Australia. Marine ecology progress series 41: 147-153.

Hopkinson, C. S., and J. J. Vallino. 2005. Efficient export of carbon to the deep ocean through dissolved organic matter. Nature 433: 142-145.

Hopkinson, C. S., J. J. Vallino, and A. Nolin. 2002. Decomposition of dissolved organic matter from the continental margin. Deep-Sea research part II 49: 4461-4478.

Jickells, T., A. R. Baker, J. N. Cape, S. E. Cornell, and E. Nemitz. 2013. The cycling of organic nitrogen through the atmosphere. Philosophical transactions of the Royal Society of London. Series B, Biological sciences 368: 20130115.

Kahler, P., and W. Koeve. 2001. Marine dissolved organic matter; can its C:N ratio explain carbon overconsumption? Deep-Sea research part I 48: 49-62.

Karl, D. M., and K. M. Björkman. 2015. Dynamics of Dissolved Organic Phosphorus, p. 233334. In D. A. Hansell and C. A. Carlson [eds.], Biogeochemistry of marine dissolved organic matter.

Kawasaki, N., and R. Benner. 2006. Bacterial release of dissolved organic matter during cell growth and decline: Molecular origin and composition. Limnology and Oceanography 51: $2170-2180$.

Keil, R. G., and L. M. Mayer. 2014. Mineral Matrices and Organic Matter, p. 337-359. In H. Holland and K. Turekian [eds.], Treatise on Geochemistry 2nd Edition.

Kieber, R. J., L. H. Hydro, and P. J. Seaton. 1997. Photooxidation of triglycerides and fatty acids in seawater: Implication toward the formation of marine humic substances. Limnology and Oceanography 42: 1454-1462.

Kieber, R. J., R. F. Whitehead, S. N. Reid, J. D. Willey, and P. J. Seaton. 2006. Chromophoric Dissolved Organic Matter (CDOM) In Rainwater, Southeastern North Carolina, USA. Journal of Atmospheric Chemistry 54: 21-41.

Koroleff, F. 1983. Simultaneous oxidation of nitrogen and phosphorus compounds by persulfate, p. 168-169. In K. Grasshoff, M. Eberhardt and K. Kremling [eds.], Methods of Seawater Analysis. Verlag Chemie.

Kubo, A., M. Yamamoto-Kawai, and J. Kanda. 2015. Seasonal variations in concentration and lability of dissolved organic carbon in Tokyo Bay. Biogeosciences 12: 269-279.

Lambrechts, J. and others 2010. Importance of wave-induced bed liquefaction in the fine sediment budget of Cleveland Bay, Great Barrier Reef. Estuarine, Coastal and Shelf Science 89: 154-162. 
Lechtenfeld, O. J., N. Hertkorn, Y. Shen, M. Witt, and R. Benner. 2015. Marine sequestration of carbon in bacterial metabolites. Nature communications 6: 6711.

Letscher, R. T., and J. K. Moore. 2015. Preferential remineralization of dissolved organic phosphorus and non-Redfield DOM dynamics in the global ocean: Impacts on marine productivity, nitrogen fixation, and carbon export. Global Biogeochemical Cycles 29: 325-340.

Lønborg, C., and X. A. Álvarez-Salgado. 2012. Recycling versus export of bioavailable dissolved organic matter in the coastal ocean and efficiency of the continental shelf pump. Global biogeochemical cycles 26.

Lønborg, C., X. A. Álvarez-Salgado, K. Davidson, and A. E. J. Miller. 2009a. Production of bioavailable and refractory dissolved organic matter by coastal heterotrophic microbial populations. Estuarine, Coastal and Shelf science.

Lønborg, C., K. Davidson, X. A. Álvarez-Salgado, and A. E. J. Miller. 2009b. Bioavailability and bacterial degradation rates of dissolved organic matter in a temperate coastal area during an annual cycle. Marine Chemistry 113: 219-226.

Lønborg, C. and others 2016. Marine Monitoring Program: Annual Report for inshore water quality monitoring: 2014 to 2015. Report for the Great Barrier Reef Marine Park Authority. , p. 229. Australian Institute of Marine Science and JCU TropWATER,.

Lønborg, C., J. Doyle, M. Furnas, P. Menendez, J. Benthuysen, and C. Carreira. 2017. Seasonal organic matter dynamics in the Great Barrier Reef lagoon: contribution of carbohydrates and proteins. Continental Shelf Research 38: 95-105.

Luick, J. L., L. Mason, T. Hardy, and M. J. Furnas. 2007. Circulation in the Great Barrier Reef Lagoon using numerical tracers and in situ data. Continental Shelf Research 27: 757-778.

Massana, R., C. Pedrós-Alió, E. O. Casamayor, and J. M. Gasol. 2001. Changes in marine bacterioplankton phylogenetic composition during incubations designed to measure biogeochemically significant parameters. Limnology and Oceanography 46: 11811188.

Mayer, L. M., L. L. Schick, K. R. Hardy, and M. L. Estapa. 2009. Photodissolution and other photochemical changes upon irradiation of algal detritus. Limnology and oceanography 54: 1688-1698.

Mayer, L. M., K. H. Thornton, and L. L. Schick. 2011. Bioavailability of organic matter photodissolved from coastal sediments. Aquatic Microbial Ecology 64: 275-284.

Mcdonnell, A. M. P., P. W. Boyd, and K. O. Buesseler. 2015. Effects of sinking velocities and microbial respiration rates on the attenuation of particulate carbon fluxes through the mesopelagic zone. Global Biogeochemical Cycles 29: 175-193.

Mckinnon, A. D., M. Logan, S. A. Castine, and S. Duggan. 2013. Pelagic metabolism in the waters of the Great Barrier Reef. Limnology and Oceanography 58: 1227-1242.

Medeiros, P. M. and others 2015. Fate of the Amazon River dissolved organic matter in the tropical Atlantic Ocean. Global Biogeochemical Cycles 29: 677-690.

Meybeck, M. 1982. Carbon, Nitrogen and Phosphorus transport by world rivers. American journal of science 282: 401-450.

Møller, E. F. 2004. Sloppy feeding in marine copepods: prey-size-dependent production of dissolved organic carbon. Journal of Plankton Research 27: 27-35.

Moran, M. A., W. M. Sheldon, and J. J. Sheldon. 1999. Biodegradation of riverine dissolved organic carbon in five estuaries of the southeastern United states. Estuaries 22: 55-64.

Nagata, T., and D. L. Kirchman. 1992. Release of macromolecular organic complexes by heterotrophic marine flagellates. Marine Ecology Progress Series 83: 233-240.

Nieuwenhuize, J., Y. E. M. Maas, and J. J. Middelburg. 1994. Rapid analysis of organic carbon and nitrogen in particulate materials. Marine Chemistry 45: 217-224. 
966

967

968

969

970

971

972

973

974

975

976

977

978

979

980

981

982

983

984

985

986

987

988

989

990

Nittrouer, C. A., G. J. Brunskill, and A. G. Figueiredo. 1995. Importance of tropical coastal environments. Geo-Marine Letters 15: 121-126.

Ogawa, H., Y.Amagai, I. Koike, K. Kaiser, and R. Benner. 2001. Production of refractory dissolved organic matter by bacteria. Science 292: 917-920.

Osterholz, H., J. Niggemann, H. A. Giebel, M. Simon, and T. Dittmar. 2015. Inefficient microbial production of refractory dissolved organic matter in the ocean. Nature communications 6: 7422 .

Panagiotopoulos, C. and others 2002. Bacterial degradation of large particles in the southern Indian Ocean using in vitro incubation experiments. Organic Geochemistry 33: 985 1000.

Raymond, P. A., and R. G. M. Spencer. 2015. Riverine DOM, p. 509-533. In D. A. Hansell and C. A. Carlson [eds.], Biogeochemistry of Marine Dissolved Organic Matter. Elsevier.

Redfield, A. C., B. K. Ketchum, and F. A. Richards. 1963. The influence of organisms on the composition of sea-water, p. 26- 77. In M. N. Hill [ed.], The sea, vol. 2, The composition of sea water: Comparative and descriptive oceanography. WileyInterscience.

Repeta, D. J. 2015. Chemical Characterization and Cycling of Dissolved Organic Matter, p. 21-63. In D. A. Hansell and C. A. Carlson [eds.], Biogeochemistry of Marine Dissolved Organic Matter.

Revelante, N., and M. Gilmartin. 1982. Dynamics of phytoplankton in the Great Barrier Reef lagoon. Journal of Plankton Research 4: 47-76.

Rontani, J.-F. and others 2014. Degradation of sterols and terrigenous organic matter in waters of the Mackenzie Shelf, Canadian Arctic. Organic Geochemistry 75: 61-73.

Santos, I. R., B. D. Eyre, and M. Huettel. 2012. The driving forces of porewater and groundwater flow in permeable coastal sediments: A review. Estuarine, Coastal and Shelf Science 98: 1-15.

Sanudo-Wilhelmy, S. A., A. Tovar-Sanchez, F.-X. Fu, D. G. Capone, E. J. Carpenter, and D. A. Hutchins. 2004. The impact of surface-adsorbed phosphorus on phytoplankton Redfield stoichiometry. Nature 432: 897-901.

Seiki, T., E. Date, and H. Izawa. 1991. Decomposition Characteristics of Particulate Organic Matter in Hiroshima Bay. Journal of oceanography 47: 207-220.

Sempéré, R., S. C. Yoro, F. Van Wambeke, and B. Charrière. 2000. Microbial decomposition of large organic particles in the northwestern Mediterranean Sea: an experimental approach. Marine ecology progress series 198: 61-72.

Sipler, R. E., and D. A. Bronk. 2015. Dynamics of Dissolved Organic Nitrogen, p. 127-232. In D. A. Hansell and C. A. Carlson [eds.], Biogeochemistry of Marine Dissolved Organic Matter.

Smith, D. C., M. Simon, A. L. Alldredge, and F. Azam. 1992. Intense hydrolytic enzyme activity on marine aggregates and implications for rapid particle dissolution. Nature 359: 139-142.

Sokal, F. F., and F. J. Rohlf. 1995. Biometry. Freeman.

Søndergaard, M. 1981. Kinetics of Extracellular Release of 14 C-Labelled Organic Carbon by Submerged Macrophytes. Oikos 36: 331-347.

Teira, E., S. Martinez-Garcia, C. Lønborg, and X. A. Álvarez-Salgado. 2009. Growth rates of different phylogenetic bacterioplankton groups in a coastal upwelling system. Enviromental Microbiology Reports 1: 545-554.

Thingstad, T. F. and others 1999. Bacteria-protist interactions and organic matter degradation under P-limited conditions: Analysis of an enclosure experiment using a simple model Limnology and Oceanography 44: 62-79. 
991

992

993

994

995

996

997

998

999

1000

1001

1002

1003

1004

1005

1006

1007

1008

1009

1010

1011

1012

1013

1014

1015

1016

1017

1018

1019

1020

1021

1022

1023

1024

1025

1026

1027

1028

1029

1030

1031

1032

1033

Torres-Valdes, S. and others 2009. Distribution of dissolved organic nutrients and their effect on export production over the Atlantic Ocean. Global biogeochemical cycles 23.

Tranvik, L. J., and S. Bertilsson. 2001. Contrasting effects of solar UV radiation on dissolved organic sources for bacterial growth. Ecology Letters 4: 458-463.

Vahatalo, A. V., H. Aarnos, and S. Mantyniemi. 2010. Biodegradability continuum and biodegradation kinetics of natural organic matter described by the beta distribution. Biogeochemistry 100: 227-240.

Valiela, I. and others 1984. Importance of chemical composition of salt marsh litter on decay rates and feeding by detritiv. Bulletin of Marine Science 35: 261-269.

Verdugo, P. 2012. Marine microgels. Annual review of marine science 4: 375-400.

Vitousek, P. M., T. Fahey, D. W. Johnson, and M. J. Wift. 1988. Element interactions in forest ecosystems: succession, allometry and input-output budgets. Biogeochemistry 5: 7-34.

Wada, S. and others 2008. Bioavailability of macroalgal dissolved organic matter in seawater. Marine Ecology Progress Series 370: 33-44.

Wakeham, S. G., C. Lee, J. I. Hedges, P. J. Hernes, and M. L. Peterson. 1997. Molecular indicators of diagenetic status in marine organic matter. Geochimica et Cosmochimica Acta 61: 5363-5369.

Ward, N. D. and others 2016. The reactivity of plant-derived organic matter and the potential importance of priming effects along the lower Amazon River. Journal of Geophysical Research: Biogeosciences 121: 1522-1539.

Ward, N. D. and others 2013. Degradation of terrestrially derived macromolecules in the Amazon River. Nature Geoscience 6: 530-533.

Wetz, M. S., B. Hales, and P. A. Wheeler. 2008. Degradation of phytoplankton-derived organic matter: Implications for carbon and nitrogen biogeochemistry in coastal ecosystems. Estuarine, Coastal and Shelf science: 422-432.

Wolanski, E. 1994. Physical Oceanographic Processes of the Great Barrier Reef. CRC Press, Boca Raton.

Wollast, R. 1998. Evaluation and comparison of the global carbon cycle in the coastal zone and in the open ocean, p. 213-252. In K. H. Brink and A. R. Robinson [eds.], The Sea, vol. 10, The Global Coastal Ocean: Processes and Methods. John Wiley.

Yamashita, Y., and E. Tanoue. 2008. Production of bio-refractory fluorescent dissolved organic matter in the ocean interior. Nature Geoscience 1: 579-582.

Yentsch, C. S., and D. W. Menzel. 1963. A method for the determination of phytoplankton chlorophyll and phaeophytin by fluorescence. Deep-sea research Oceanographic Abstracts 10: 221-231.

\section{Acknowledgments}

Financial support for this study was provided by the Australian Institute of Marine Science.

We thank the crew of the R.V. Cape Ferguson for help at sea. The help of the Cruise leader

(Irena Zagorskis) and other participants (Paul Costello and Johnstone Davidson) in obtaining

the field data is also acknowledged. The field data included in the manuscript was obtained

with support from the Great Barrier Reef Marine Park Authority, through funding from the 
1034 Australian Government Reef Program and from the Australian Institute of Marine Science.

1035 X.A.A.S was support by the CSIC project FOMEM (grant No PIE 201030E130). 


\section{Figure legends}

1037 Fig. 1. Map showing the three sampling stations $(\bullet)$ that were sampled during three cruises 1038 aboard R/V Cape Ferguson in the period September 2014 to June 2015. The offshore 1039 arrows show the East Australian Current (EAC) which flows poleward and enters onto the 1040 shelf and outer lagoon by passages between reefs. The arrow close to shore indicates the

Fig. 4. Example of the time evolution, of a) total (TOC) particulate (POC) and dissolved organic carbon (DOC), b) total nitrogen $(\mathrm{TN})$, particulate organic nitrogen (PON), dissolved inorganic (DIN) and organic (DON) nitrogen; c) total phosphorus (TP), particulate organic phosphorus (POP) dissolved inorganic (DIP) and organic (DOP) phosphorus in the experiment conducted at sta. 3 in the late dry season. Error bars represent standard errors.

Fig. 5. Average distribution of bioavailable a) phosphorus and b) nitrogen between dissolved inorganic nutrients, particulate and dissolved organic matter from the three different 
1060 stations in Late dry (September 2014), Wet (February 2015) and Early dry seasons (June 1061 2015). Error bars represent standard errors.

1062 Fig. 6. X-Y plots of (a) B-PN versus B-POC (•), BDON with BDOC (०), (b) B-PP versus B$1063 \operatorname{POC}(\bullet)$, BDOP with BDOC (०) and (c) B-PP versus B-PN (•), BDOP with BDON (o). 1064 Solid and dashed lines represent the corresponding regression and error bars are standard 1065 errors. $\mathrm{R}^{2}=$ coefficient of determination, $\mathrm{p}=$ significant level.

1066 
1067 Table 1. Meteorological conditions, and physical, chemical and biological properties of the surface (5 m) water samples at the time of

1068 collection. Wind direction (Wind dir.) and speed are shown together with average values for salinity (Sal.), temperature (Temp.), Secchi disk

1069 depth, total suspended solids (TSS), chlorophyll $a(\mathrm{Chl} a)$, dissolved inorganic nitrogen (DIN $\left.=\mathrm{NH}_{4}{ }^{+}+\mathrm{NO}_{3}{ }^{-} / \mathrm{NO}_{2}{ }^{-}\right)$and phosphorus (DIP),

1070 particulate organic carbon (POC), nitrogen (PN) and phosphorus (PP) are shown. Standard deviations are shown for Chl $a$, nutrient and

1071 particulate organic matter data.

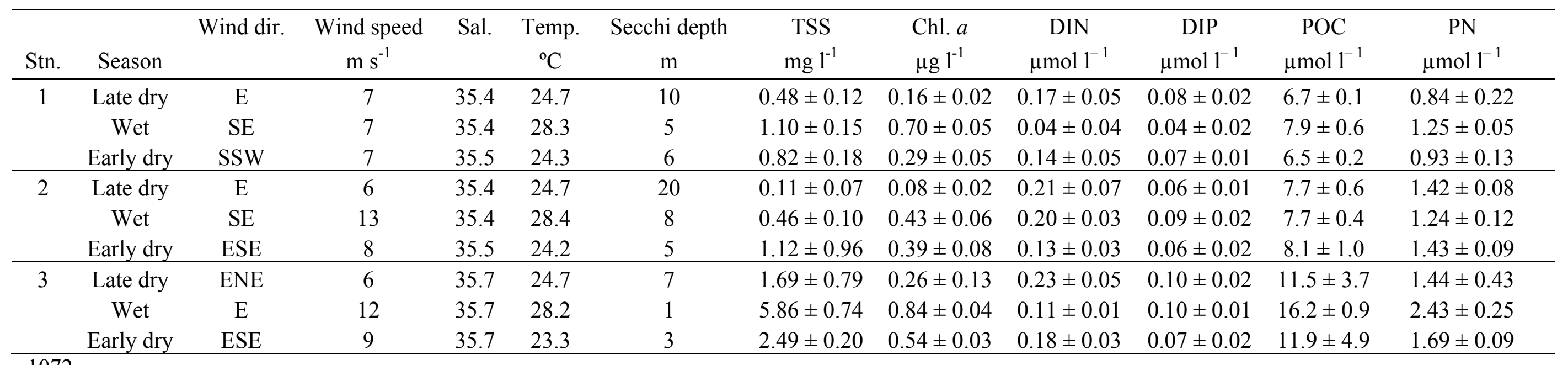


Table 2. Initial (POC, PN, PP, DOC, DON, DOP), recalcitrant (R-POC, R-PN, R-PP, R-DOC, R-DON, R-DOP), and bioavailable (B-POC, B-

1074 PN, B-PP, B-DOC, B-DON, B-DOP) concentrations of a) particulate (POM) and b) dissolved organic matter (DOM) determined during the

1075 experiments. Values are averages \pm standard error.

\begin{tabular}{|c|c|c|c|c|c|c|c|c|c|c|}
\hline Station & Season & $\begin{array}{c}\text { POC } \\
\mu \mathrm{mol} \mathrm{L}^{-1}\end{array}$ & $\begin{array}{c}\text { B-POC } \\
\mu \mathrm{mol} \mathrm{L}^{-1}\end{array}$ & $\begin{array}{c}\text { R-POC } \\
\mu \mathrm{mol} \mathrm{L}^{-1}\end{array}$ & $\begin{array}{c}\mathrm{PN} \\
\mu \mathrm{mol} \mathrm{L}^{-1}\end{array}$ & $\begin{array}{c}\text { B-PN } \\
\mu \mathrm{mol} \mathrm{L}^{-1}\end{array}$ & $\begin{array}{c}\text { R-PN } \\
\mu \mathrm{mol} \mathrm{L}^{-1}\end{array}$ & $\begin{array}{c}\text { PP } \\
\mu \mathrm{mol} \mathrm{L}\end{array}$ & $\begin{array}{c}\text { B-PP } \\
\mu \mathrm{mol} \mathrm{L}^{-1}\end{array}$ & $\begin{array}{c}\text { R-PP } \\
\mu \mathrm{mol} \mathrm{L}^{-1}\end{array}$ \\
\hline \multirow[t]{3}{*}{1} & Late dry & $24 \pm 8$ & $12 \pm 9$ & $12 \pm 2$ & $3.4 \pm 1.3$ & $2.4 \pm 1.4$ & $1.0 \pm 0.2$ & $0.20 \pm 0.03$ & $0.17 \pm 0.09$ & $0.03 \pm 0.05$ \\
\hline & Wet & $18 \pm 2$ & $11 \pm 4$ & $10 \pm 2$ & $3.6 \pm 0.2$ & $2.5 \pm 0.8$ & $1.1 \pm 0.6$ & $0.14 \pm 0.03$ & $0.12 \pm 0.05$ & $0.02 \pm 0.01$ \\
\hline & Early dry & $21 \pm 2$ & $12 \pm 3$ & $9 \pm 1$ & $3.6 \pm 0.5$ & $2.7 \pm 0.7$ & $0.9 \pm 0.2$ & $0.21 \pm 0.02$ & $0.19 \pm 0.05$ & $0.01 \pm 0.03$ \\
\hline \multirow[t]{3}{*}{2} & Late dry & $25 \pm 3$ & $14 \pm 4$ & $11 \pm 1$ & $4.7 \pm 0.7$ & $3.6 \pm 0.9$ & $1.1 \pm 0.2$ & $0.20 \pm 0.02$ & $0.18 \pm 0.07$ & $0.02 \pm 0.06$ \\
\hline & Wet & $15 \pm 3$ & $8 \pm 5$ & $7 \pm 2$ & $3.0 \pm 0.2$ & $2.0 \pm 0.5$ & $1.0 \pm 0.3$ & $0.13 \pm 0.04$ & $0.12 \pm 0.11$ & $0.01 \pm 0.07$ \\
\hline & Early dry & $16 \pm 3$ & $7 \pm 5$ & $8 \pm 1$ & $2.6 \pm 1.4$ & $2.0 \pm 1.8$ & $0.6 \pm 0.4$ & $0.13 \pm 0.02$ & $0.12 \pm 0.05$ & $0.01 \pm 0.03$ \\
\hline \multirow[t]{3}{*}{3} & Late dry & $39 \pm 3$ & $29 \pm 6$ & $10 \pm 3$ & $5.6 \pm 0.3$ & $4.9 \pm 1.2$ & $0.7 \pm 0.9$ & $0.38 \pm 0.06$ & $0.35 \pm 0.16$ & $0.03 \pm 0.10$ \\
\hline & Wet & $27 \pm 2$ & $17 \pm 3$ & $9 \pm 2$ & $5.1 \pm 0.6$ & $4.2 \pm 0.9$ & $0.9 \pm 0.2$ & $0.23 \pm 0.03$ & $0.21 \pm 0.04$ & $0.02 \pm 0.02$ \\
\hline & Early dry & $21 \pm 2$ & $12 \pm 3$ & $9 \pm 1$ & $3.8 \pm 0.4$ & $2.8 \pm 0.9$ & $1.0 \pm 0.5$ & $0.18 \pm 0.04$ & $0.17 \pm 0.06$ & $0.01 \pm 0.02$ \\
\hline & & $\mathrm{DOC}$ & B-DOC & R-DOC & DON & B-DON & R-DON & DOP & B-DOP & R-DOP \\
\hline Station & Season & $\mu \mathrm{mol} \mathrm{L}{ }^{-1}$ & $\mu \mathrm{mol} \mathrm{L}{ }^{-1}$ & $\mu \mathrm{mol} \mathrm{L}{ }^{-1}$ & $\mu \mathrm{mol} \mathrm{L}{ }^{-1}$ & $\mu \mathrm{mol} \mathrm{L}{ }^{-1}$ & $\mu \mathrm{mol} \mathrm{L}{ }^{-1}$ & $\mu \mathrm{mol} \mathrm{L}{ }^{-1}$ & $\mu \mathrm{mol} \mathrm{L}{ }^{-1}$ & $\mu \mathrm{mol} \mathrm{L}{ }^{-1}$ \\
\hline \multirow[t]{3}{*}{1} & Late dry & $74 \pm 1$ & $12 \pm 5$ & $61 \pm 4$ & $5.5 \pm 0.7$ & $1.8 \pm 1.3$ & $3.7 \pm 0.6$ & $0.22 \pm 0.01$ & $0.15 \pm 0.06$ & $0.07 \pm 0.05$ \\
\hline & Wet & $84 \pm 2$ & $21 \pm 4$ & $63 \pm 2$ & $6.2 \pm 1.0$ & $2.5 \pm 1.3$ & $3.7 \pm 0.3$ & $0.28 \pm 0.04$ & $0.21 \pm 0.07$ & $0.07 \pm 0.04$ \\
\hline & Early dry & $74 \pm 1$ & $12 \pm 3$ & $62 \pm 2$ & $6.0 \pm 0.4$ & $2.0 \pm 0.5$ & $4.0 \pm 0.1$ & $0.25 \pm 0.02$ & $0.16 \pm 0.08$ & $0.08 \pm 0.06$ \\
\hline \multirow[t]{3}{*}{2} & Late dry & $57 \pm 1$ & $6 \pm 5$ & $51 \pm 4$ & $4.7 \pm 0.3$ & $1.5 \pm 0.5$ & $3.2 \pm 0.3$ & $0.16 \pm 0.05$ & $0.09 \pm 0.08$ & $0.07 \pm 0.04$ \\
\hline & Wet & $75 \pm 3$ & $15 \pm 5$ & $61 \pm 1$ & $5.0 \pm 0.4$ & $1.7 \pm 0.8$ & $3.3 \pm 0.4$ & $0.21 \pm 0.02$ & $0.16 \pm 0.08$ & $0.05 \pm 0.06$ \\
\hline & Early dry & $80 \pm 1$ & $18 \pm 2$ & $61 \pm 1$ & $6.0 \pm 0.6$ & $2.0 \pm 0.9$ & $4.0 \pm 0.3$ & $0.25 \pm 0.04$ & $0.17 \pm 0.06$ & $0.08 \pm 0.02$ \\
\hline \multirow[t]{3}{*}{3} & Late dry & $75 \pm 2$ & $8 \pm 3$ & $67 \pm 1$ & $5.6 \pm 1.0$ & $1.5 \pm 1.4$ & $4.1 \pm 0.4$ & $0.24 \pm 0.03$ & $0.14 \pm 0.06$ & $0.09 \pm 0.04$ \\
\hline & Wet & $80 \pm 1$ & $11 \pm 4$ & $69 \pm 2$ & $5.7 \pm 0.4$ & $1.6 \pm 0.5$ & $4.0 \pm 0.1$ & $0.21 \pm 0.01$ & $0.13 \pm 0.02$ & $0.08 \pm 0.01$ \\
\hline & Early dry & $76 \pm 1$ & $10 \pm 2$ & $67 \pm 1$ & $6.2 \pm 0.7$ & $1.9 \pm 1.2$ & $4.5 \pm 0.5$ & $0.23 \pm 0.05$ & $0.19 \pm 0.15$ & $0.04 \pm 0.04$ \\
\hline
\end{tabular}


1077 Table 3. Matrix of the correlation coefficient $\left(R^{2}\right)$ of the significant $(p<0.05)$ linear

1078 regressions between DOM bioavailability and environmental parameters.

\begin{tabular}{cccc}
\hline $\mathrm{X} / \mathrm{Y}$ & $\mathrm{BDOC}$ & $\mathrm{BDON}$ & $\mathrm{BDOP}$ \\
\hline $\mathrm{Chl} a$ & $0.48^{*}$ & $0.60^{*}$ & $0.79^{*}$ \\
$\mathrm{DIN}$ & 0.58 & 0.70 & 0.34 \\
$\mathrm{DIP}$ & 0.60 & 0.93 & 0.73 \\
\hline
\end{tabular}

*Data from station 3 in February 2015 have been omitted to reach significant levels. 
1080 Table 4. Significant regressions between bioavailable DOM, and inorganic nutrients (DIN,

1081 DIP), and total and bioavailable POM and DOM, and the degradation rate constants. Slope,

1082 intercept, and standard error are values found by Model II regression. $\mathrm{R}^{2}=$ coefficient of 1083 determination, $\mathrm{p}=$ significant levels and n.s. - not significant. In all cases the number of 1084 observations (n) equals 9.

\begin{tabular}{|c|c|c|c|c|c|c|}
\hline Eq. & $\mathrm{X}$ & $\mathrm{Y}$ & Slope $( \pm \mathrm{SE})$ & Intercept $( \pm \mathrm{SE})$ & $\mathrm{R}^{2}$ & $\mathrm{p}$ \\
\hline 1 & B-DON & DIN & $-0.19 \pm 0.05$ & $0.49 \pm 0.07$ & 0.70 & $<0.005$ \\
\hline 2 & B-DOP & DIP & $-0.54 \pm 0.12$ & $0.16 \pm 0.02$ & 0.73 & $<0.004$ \\
\hline 3 & B-POC & POC & $1.1 \pm 0.1$ & $8 \pm 1$ & 0.96 & $<0.0002$ \\
\hline 4 & B-PN & PON & $1.0 \pm 0.1$ & $0.9 \pm 0.2$ & 0.98 & $<0.0001$ \\
\hline 5 & B-PP & POP & $1.1 \pm 0.1$ & $0.01 \pm 0.01$ & 0.99 & $<0.0001$ \\
\hline 6 & B-DOC & DOC & $1.6 \pm 0.6$ & $55 \pm 5$ & 0.53 & $<0.03$ \\
\hline 7 & B-DON & DON & $1.2 \pm 0.6$ & $3.4 \pm 0.8$ & 0.52 & $<0.02$ \\
\hline 8 & B-DOP & DOP & $1.0 \pm 0.2$ & $0.07 \pm 0.03$ & 0.77 & $<0.002$ \\
\hline 9 & $\mathrm{k}_{\mathrm{PN}}$ & $\mathrm{k}_{\mathrm{POC}}$ & $0.86 \pm 0.23$ & n.s & 0.76 & $<0.005$ \\
\hline 10 & $\mathrm{k}_{\mathrm{PP}}$ & $\mathrm{k}_{\mathrm{POC}}$ & $0.73 \pm 0.26$ & n.s & 0.65 & $<0.02$ \\
\hline 11 & $\mathrm{k}_{\mathrm{PP}}$ & $\mathrm{k}_{\mathrm{PN}}$ & $0.85 \pm 0.27$ & n.s & 0.61 & $<0.02$ \\
\hline 12 & $\mathrm{k}_{\mathrm{DON}}$ & $\mathrm{k}_{\mathrm{DOC}}$ & $0.82 \pm 0.11$ & n.s & 0.87 & $<0.0003$ \\
\hline 13 & $\mathrm{k}_{\mathrm{DOP}}$ & $\mathrm{k}_{\mathrm{DOC}}$ & $0.55 \pm 0.06$ & n.s & 0.94 & $<0.0001$ \\
\hline 14 & $\mathrm{k}_{\mathrm{DOP}}$ & $\mathrm{k}_{\mathrm{DON}}$ & $0.67 \pm 0.15$ & n.s & 0.83 & $<0.001$ \\
\hline 15 & B-POC & $\mathrm{k}_{\mathrm{POC}}$ & $(6 \pm 2) \times 10^{-3}$ & $0.16 \pm 0.02$ & 0.58 & $<0.02$ \\
\hline 16 & B-PN & $\mathrm{k}_{\mathrm{PN}}$ & $0.13 \pm 0.03$ & $0.18 \pm 0.03$ & 0.55 & $<0.03$ \\
\hline 17 & B-PP & $\mathrm{k}_{\mathrm{PP}}$ & $2.8 \pm 0.3$ & $0.23 \pm 0.03$ & 0.59 & $<0.02$ \\
\hline 18 & B-DOC & $\mathrm{k}_{\mathrm{DOC}}$ & $(10 \pm 2) \times 10^{-3}$ & n.s & 0.73 & $<0.004$ \\
\hline 19 & B-DON & $\mathrm{k}_{\mathrm{DON}}$ & $0.09 \pm 0.08$ & n.s & 0.50 & $<0.04$ \\
\hline 20 & B-DOP & $\mathrm{k}_{\mathrm{DOP}}$ & $1.6 \pm 0.4$ & n.s & 0.78 & $<0.002$ \\
\hline
\end{tabular}


Table 5. Degradation rate constants ( \pm standard error) obtained by fitting the exponential

1087 decay model to the decrease in carbon, nitrogen and phosphorus in the a) particulate ( $\mathrm{k}_{\mathrm{POC}}$,

$1088 \mathrm{k}_{\mathrm{PON}}$ and $\left.\mathrm{k}_{\mathrm{POP}}\right)$ and $\mathrm{b}$ ) dissolved organic matter pools $\left(\mathrm{k}_{\mathrm{DOC}}, \mathrm{k}_{\mathrm{DON}}\right.$ and $\left.\mathrm{k}_{\mathrm{DOP}}\right) . \mathrm{R}^{2}=$ coefficient

1089 of determination. In all cases the number of point (n) equals 5.

\begin{tabular}{|c|c|c|c|c|c|c|c|}
\hline Station & Season & $\mathrm{k}_{\mathrm{POC}}\left(\mathrm{day}^{-1}\right)$ & $\mathrm{R}^{2}$ & $\mathrm{k}_{\mathrm{PON}}\left(\right.$ day $\left.^{-1}\right)$ & $\mathrm{R}^{2}$ & $\mathrm{k}_{\mathrm{POP}}\left(\right.$ day $\left.^{-1}\right)$ & $\mathrm{R}^{2}$ \\
\hline \multirow[t]{3}{*}{1} & Late dry & $0.20 \pm 0.06$ & 0.91 & $0.26 \pm 0.05$ & 0.97 & $0.28 \pm 0.09$ & 0.87 \\
\hline & Wet & $0.25 \pm 0.01$ & 0.93 & $0.31 \pm 0.06$ & 0.96 & $0.35 \pm 0.20$ & 0.90 \\
\hline & Early dry & $0.25 \pm 0.09$ & 0.87 & $0.30 \pm 0.02$ & 0.98 & $0.34 \pm 0.04$ & 0.98 \\
\hline \multirow[t]{3}{*}{2} & Late dry & $0.22 \pm 0.03$ & 0.97 & $0.27 \pm 0.03$ & 0.98 & $0.32 \pm 0.03$ & 0.98 \\
\hline & Wet & $0.21 \pm 0.03$ & 0.98 & $0.24 \pm 0.04$ & 0.97 & $0.29 \pm 0.10$ & 0.87 \\
\hline & Early dry & $0.25 \pm 0.03$ & 0.98 & $0.26 \pm 0.06$ & 0.94 & $0.30 \pm 0.02$ & 0.98 \\
\hline \multirow[t]{3}{*}{3} & Late dry & $0.33 \pm 0.07$ & 0.93 & $0.36 \pm 0.04$ & 0.98 & $0.42 \pm 0.10$ & 0.91 \\
\hline & Wet & $0.24 \pm 0.02$ & 0.96 & $0.32 \pm 0.03$ & 0.98 & $0.35 \pm 0.10$ & 0.86 \\
\hline & Early dry & $0.22 \pm 0.04$ & 0.97 & $0.26 \pm 0.06$ & 0.91 & $0.36 \pm 0.01$ & 0.96 \\
\hline Station & Season & $\mathrm{k}_{\text {DOC }}\left(\right.$ day $\left.^{-1}\right)$ & $\mathrm{R}^{2}$ & $\mathrm{k}_{\text {DON }}\left(\right.$ day $\left.^{-1}\right)$ & $\mathrm{R}^{2}$ & $\mathrm{k}_{\mathrm{DOP}}\left(\mathrm{day}^{-1}\right)$ & $\mathrm{R}^{2}$ \\
\hline \multirow[t]{3}{*}{1} & Late dry & $0.13 \pm 0.03$ & 0.91 & $0.21 \pm 0.09$ & 0.84 & $0.26 \pm 0.11$ & 0.92 \\
\hline & Wet & $0.20 \pm 0.06$ & 0.89 & $0.25 \pm 0.07$ & 0.90 & $0.33 \pm 0.08$ & 0.94 \\
\hline & Early dry & $0.17 \pm 0.06$ & 0.84 & $0.22 \pm 0.08$ & 0.76 & $0.30 \pm 0.06$ & 0.93 \\
\hline \multirow[t]{3}{*}{2} & Late dry & $0.04 \pm 0.01$ & 0.89 & $0.05 \pm 0.01$ & 0.94 & $0.09 \pm 0.02$ & 0.94 \\
\hline & Wet & $0.17 \pm 0.05$ & 0.87 & $0.24 \pm 0.09$ & 0.87 & $0.28 \pm 0.01$ & 0.96 \\
\hline & Early dry & $0.19 \pm 0.03$ & 0.97 & $0.20 \pm 0.05$ & 0.93 & $0.33 \pm 0.04$ & 0.92 \\
\hline \multirow[t]{3}{*}{3} & Late dry & $0.11 \pm 0.01$ & 0.88 & $0.12 \pm 0.02$ & 0.98 & $0.23 \pm 0.07$ & 0.87 \\
\hline & Wet & $0.15 \pm 0.02$ & 0.98 & $0.18 \pm 0.05$ & 0.90 & $0.25 \pm 0.03$ & 0.89 \\
\hline & Early dry & $0.15 \pm 0.04$ & 0.85 & $0.20 \pm 0.06$ & 0.86 & $0.28 \pm 0.04$ & 0.98 \\
\hline
\end{tabular}

1090 


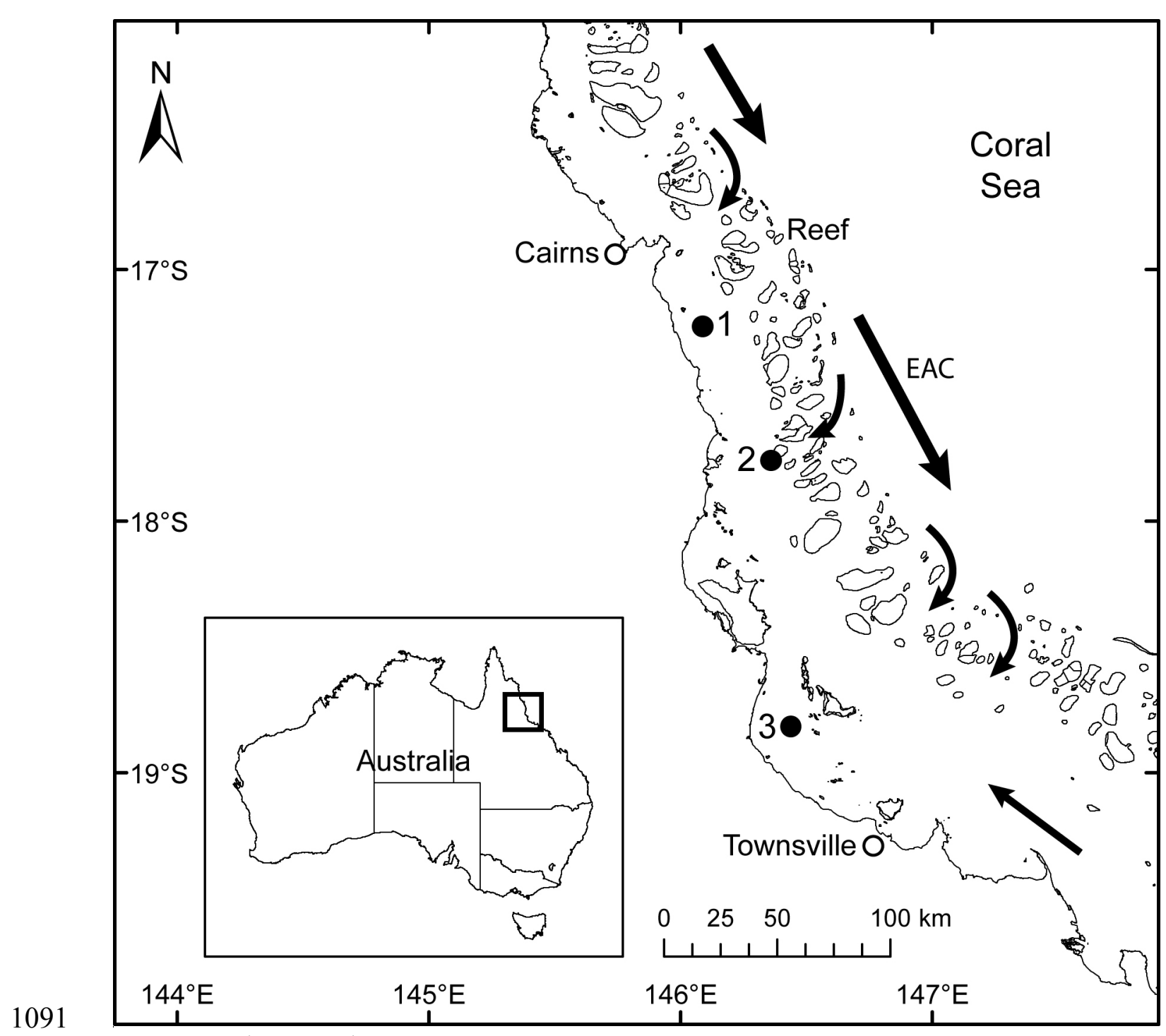

Fig. 1. Lønborg et al. 

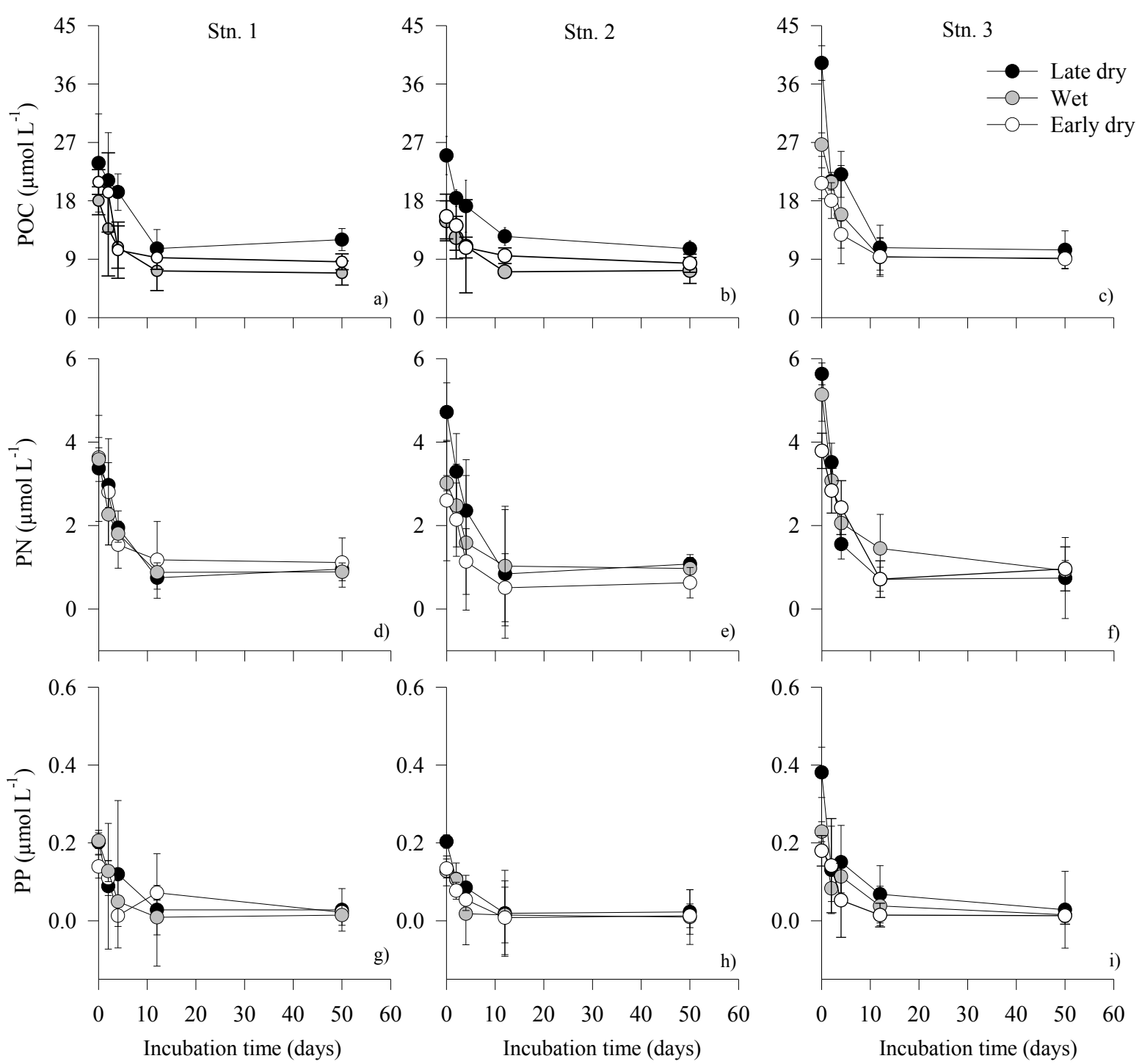

1094 Fig. 2. Lønborg et al. 

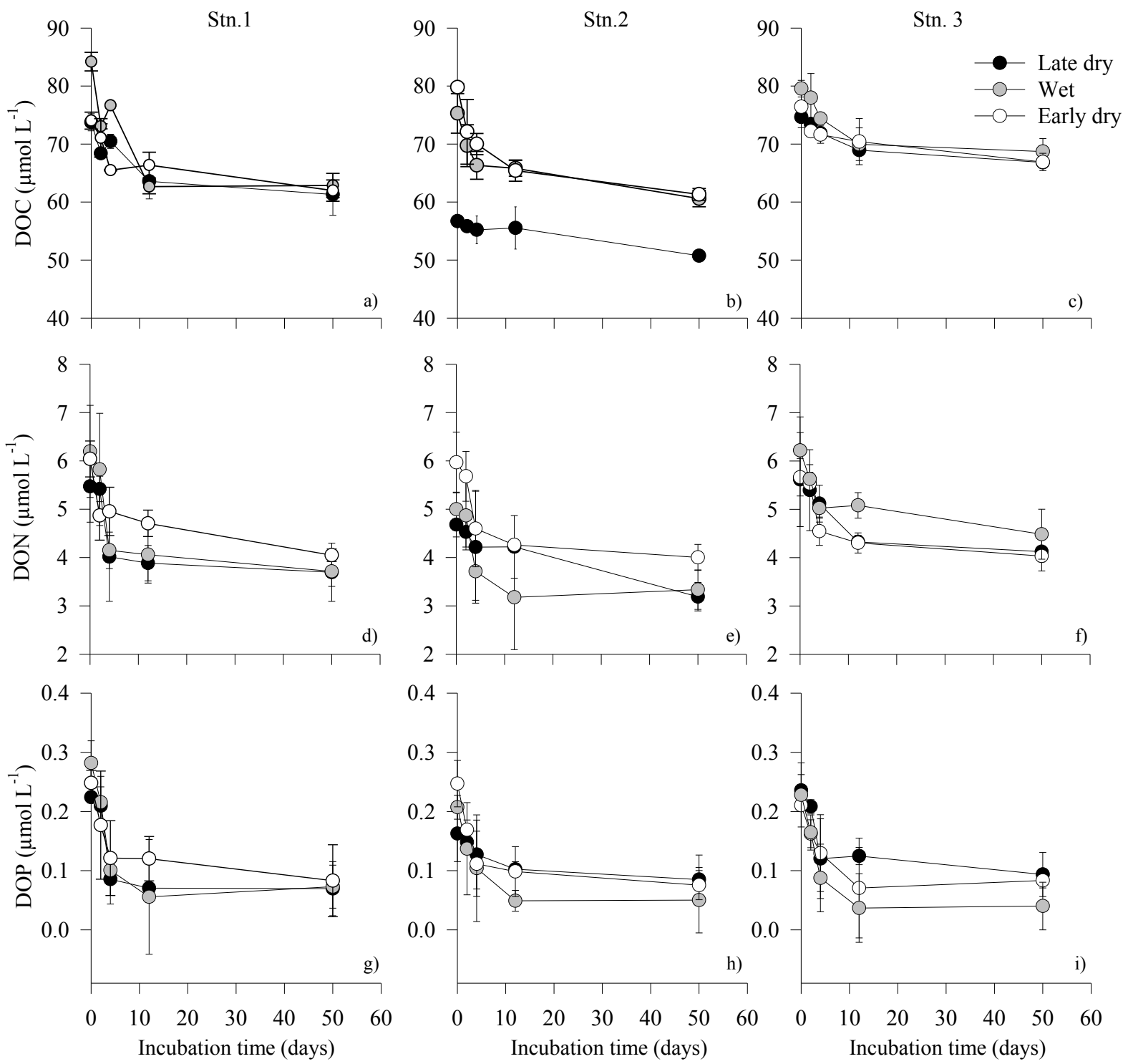

1096 Fig. 3. Lønborg et al. 

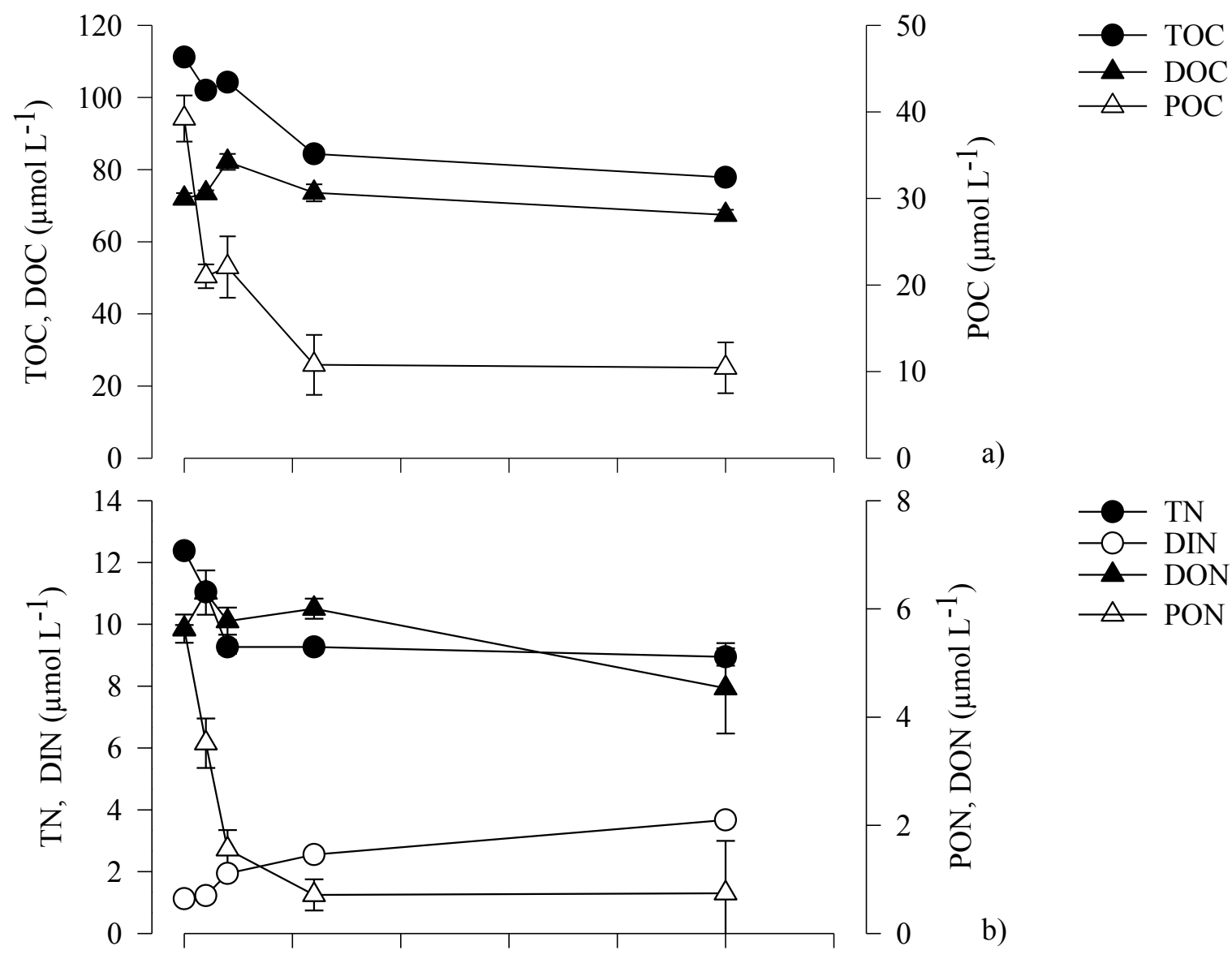

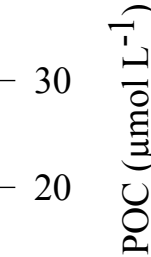

$-10$

a)
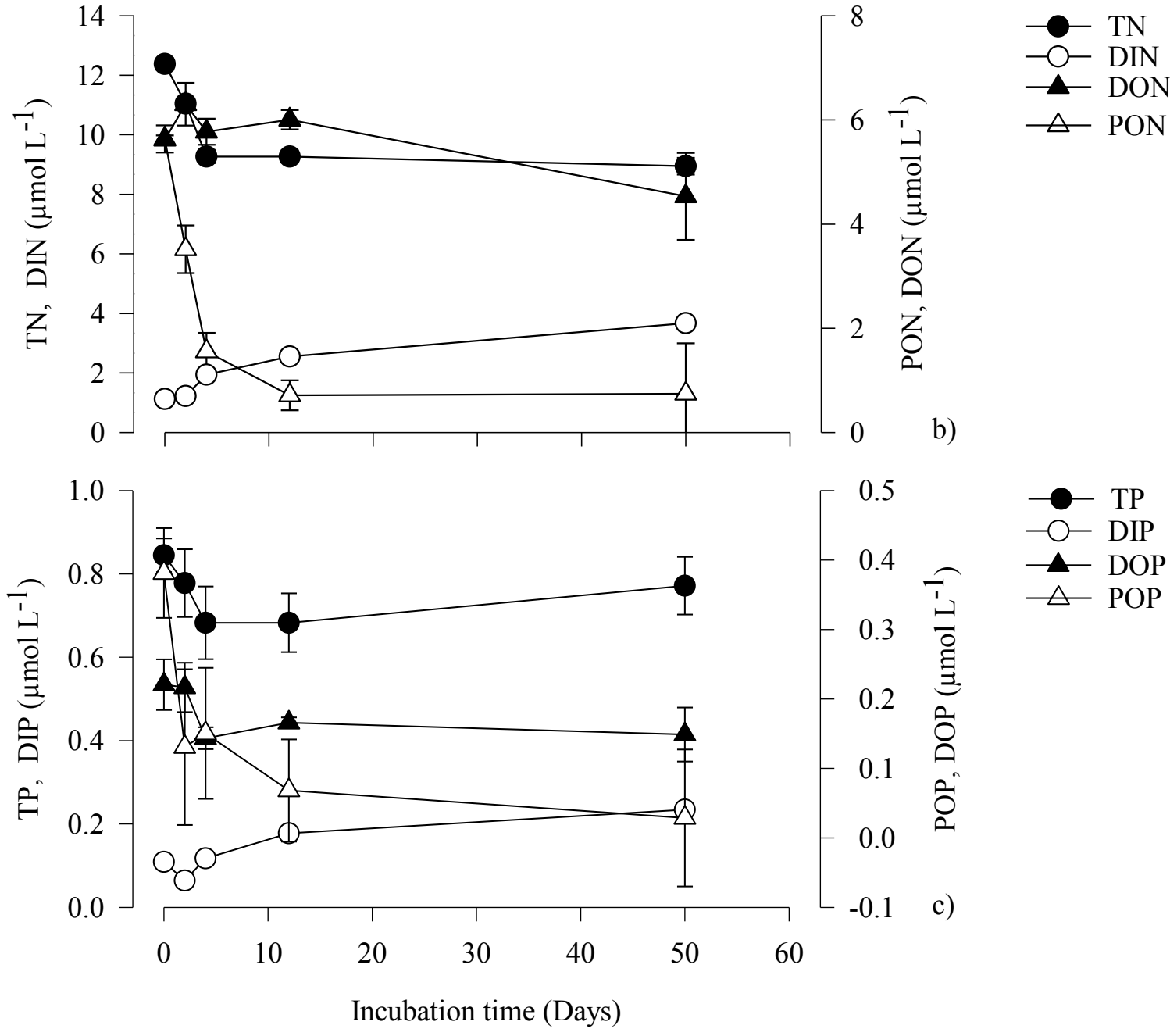

b)

1097

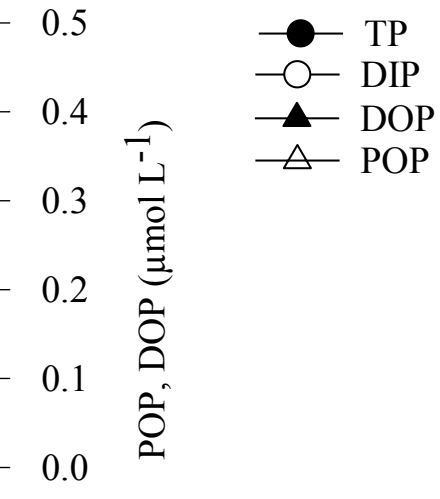

$-0.1 \quad \mathrm{c})$

1098 Fig. 4. Lønborg et al. 

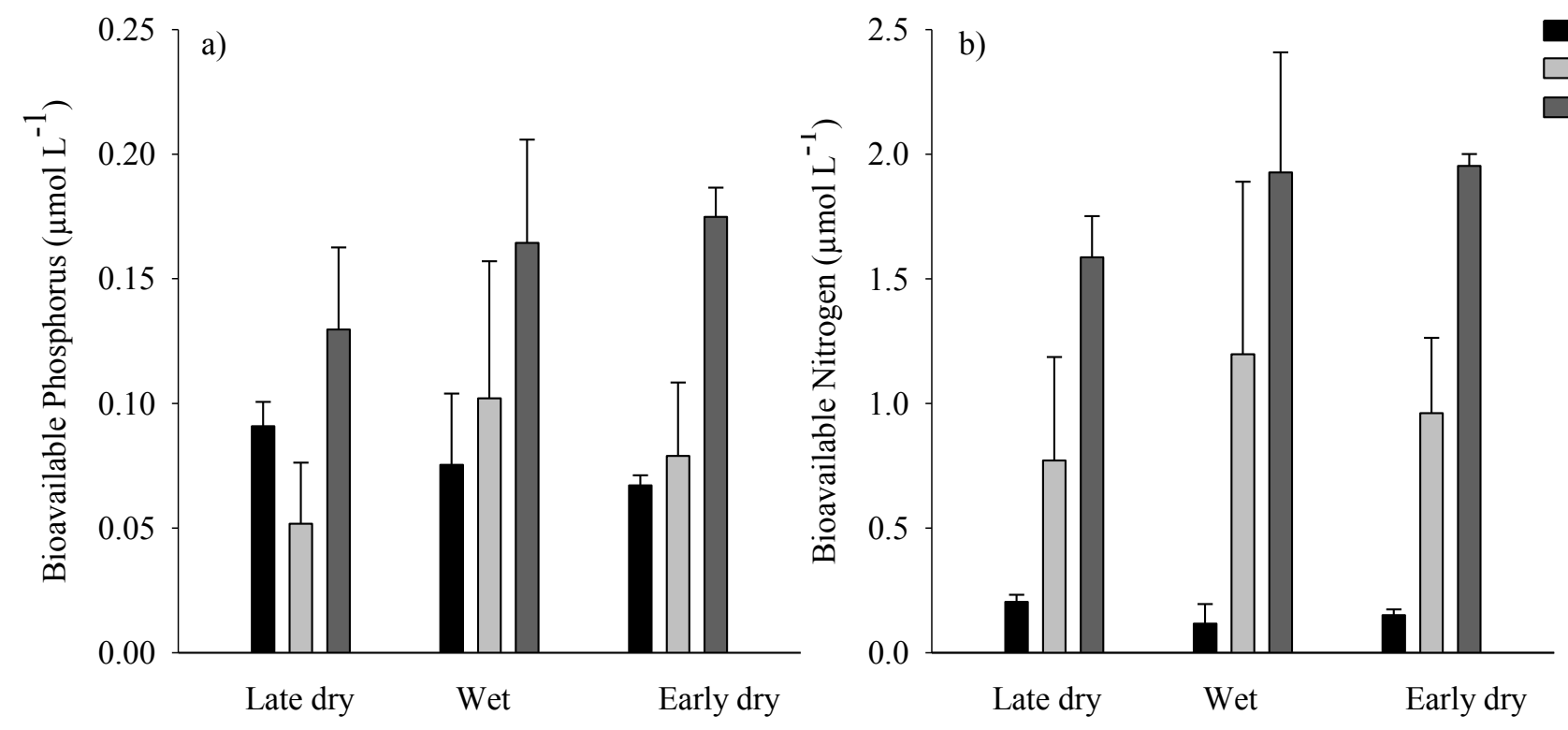

Dissolved inorganic nutrients Particulate nutrients

Dissolved organic nutrients

1100 Fig. 5. Lønborg et al. 

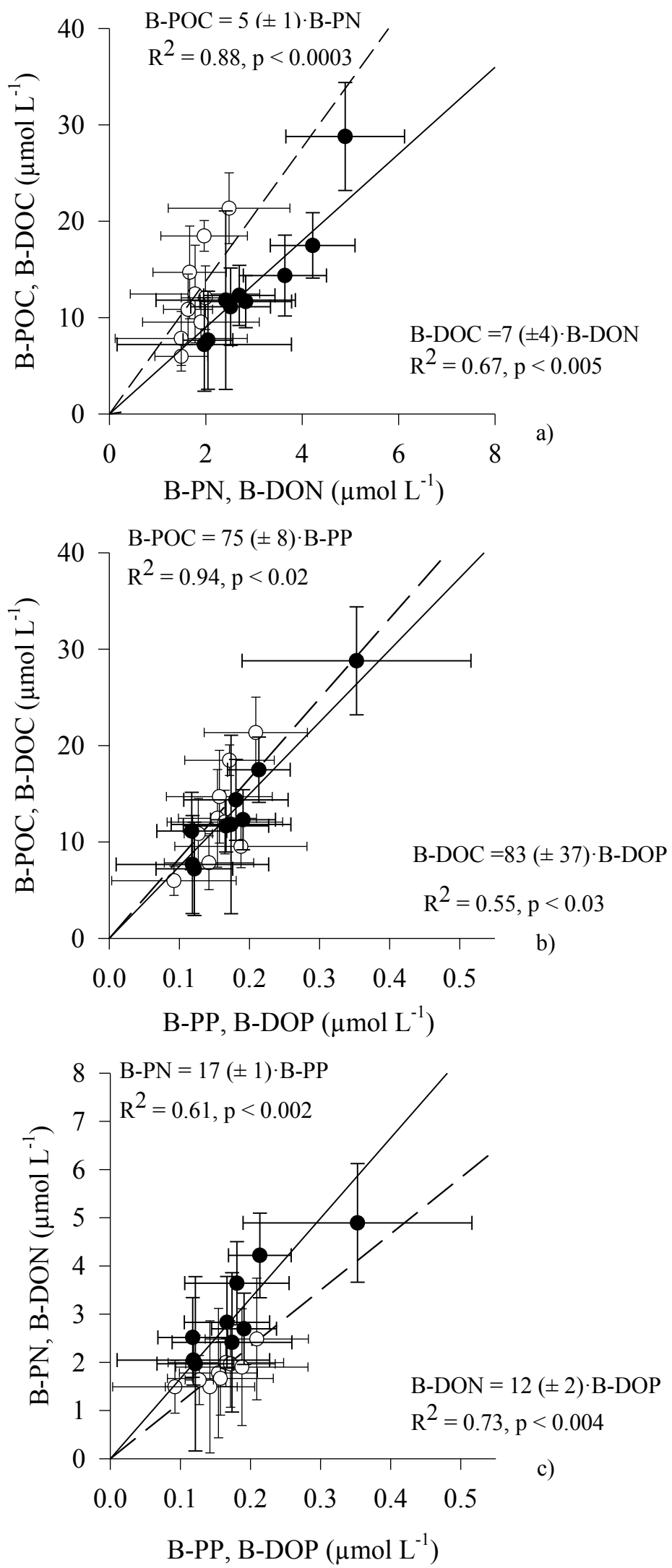

1103 Fig. 6. Lønborg et al. 